\title{
Vegetable Oils as Alternative Solvents for Green Oleo-Extraction, Purification and Formulation of Food and Natural Products
}

\author{
Edinson Yara-Varón ${ }^{1,2, *}$, Ying $\mathrm{Li}^{3, *}$ (1) , Mercè Balcells ${ }^{2}$ (1), Ramon Canela-Garayoa ${ }^{2}$ (1) \\ Anne-Sylvie Fabiano-Tixier ${ }^{1}$ and Farid Chemat ${ }^{1}$ \\ 1 Laboratoire GREEN, Université d'Avignon et des Pays de Vaucluse, INRA, UMR408, \\ GREEN Extraction Team, F-84000 Avignon, France; anne-sylvie.fabiano@univ-avignon.fr (A.-S.F.-T.); \\ farid.chemat@univ-avignon.fr (F.C.) \\ 2 Department of Chemistry, University of Lleida, Av. Alcalde Rovira Roure 191, 25198 Lleida, Spain; \\ balcells@quimica.udl.cat (M.B.); canela@quimica.udl.cat (R.C.-G.) \\ 3 Department of Food Science and Engineering, College of Science and Engineering, Jinan University, \\ Guangzhou 510632, China \\ * Correspondence: yaraa@quimica.udl.cat (E.Y.-V.); yingli@jnu.edu.cn (Y.L.); \\ Tel.: +34-973-702-840 (E.Y.-V.); +86-208-522-0032 (Y.L.)
}

Received: 14 August 2017; Accepted: 2 September 2017; Published: 5 September 2017

\begin{abstract}
Since solvents of petroleum origin are now strictly regulated worldwide, there is a growing demand for using greener, bio-based and renewable solvents for extraction, purification and formulation of natural and food products. The ideal alternative solvents are non-volatile organic compounds (VOCs) that have high dissolving power and flash point, together with low toxicity and less environmental impact. They should be obtained from renewable resources at a reasonable price and be easy to recycle. Based on the principles of Green Chemistry and Green Engineering, vegetable oils could become an ideal alternative solvent to extract compounds for purification, enrichment, or even pollution remediation. This review presents an overview of vegetable oils as solvents enriched with various bioactive compounds from natural resources, as well as the relationship between dissolving power of non-polar and polar bioactive components with the function of fatty acids and/or lipid classes in vegetable oils, and other minor components. A focus on simulation of solvent-solute interactions and a discussion of polar paradox theory propose a mechanism explaining the phenomena of dissolving polar and non-polar bioactive components in vegetable oils as green solvents with variable polarity.
\end{abstract}

Keywords: vegetable oils; alternative bio-based solvents; green oleo-extraction; natural products; polar paradox; solvent-solute simulation

\section{Historical Evolution of Vegetable Oils Applications}

At the beginning of human civilization, animal fats like butter produced from milk of horses, goats, sheep and cattle were probably used instead of vegetable oils before the discovery of oil pressing and extraction from olives or seeds afterwards [1]. In Egypt, Mesopotamia, Greece and Rome, olive oil became the primary source of oil for cooking or use as a condiment. Nevertheless, prior to their use of olive oils, the Egyptians extracted oil largely from radishes or flax seeds, and the Mesopotamians extracted it primarily from sesame seeds [1,2]. Likewise, archaeological and documentary records evidenced that sesame oil competed with the olive oil in the Mediterranean basin and India from at least 1137 BC [3]. Ancient Egyptians firstly produced infusions of medicinal or aromatic plants in vegetable oils as solvents for therapeutic, nutritional, aesthetic and spiritual purposes. They used vegetable oils in the formulation of cosmetics providing emollience, moisturizers and grooming, 
or acting as solvents and vehicles to carry other agents [4]. They also invented frying in oils or fats for the preservation of meat and vegetables around $2500 \mathrm{BC}$ [5]. In addition, recorded pictorial documents have pointed that edible vegetable oils were used as lubricating liquids as well by Egyptian pyramid builders when rolling large pieces of rocks on wooden rollers [6].

Subsequently, other ancestors such as those from ancient Greece, where wild olives were probably native, had mastered infusion of olive oils with flowers or herbs for beauty and medical treatments. The ancient Romans spread the application of such oils into ordinary lives (e.g., wall coverings, personal care, etc.) after they took over control from the Greeks. European civilizations also used oils or fats infused with aromatic plants such as cinnamon and clove to prevent plagues in the medieval period. In relation to the ancient American civilizations, oils pressed from chia and amaranth seeds were used as body emollients rather than frying. The Aztecs produced groundnut oil in South America long before the arrival of European settlers in the 15th century [3]. Other edible oils like palm oil, originated in West Africa, were spread to the Americas and Indonesia in the 16th century, but the biggest change occurred in the global lipid consumption over the last centuries. In the 18th century, the enfleurage developed in Grasse (France) used odourless animal fats to capture fragrant substances exuded by plants, which led to the production of high-grade concentrates for delicate floral botanicals such as jasmine and tuberose. However, the fats used in this out-dated method were superseded extensively by petroleum-based solvents (e.g., hexane, benzene, etc.) in the 19th century.

In addition to those mentioned above, Asians, especially the Chinese, have also made remarkable contributions to the use of animal fats and vegetable oils. According to historical records, the use of animal fats mostly for cuisine and sacrificial ceremonies remounts to the Xia-Shang-Zhou Dynasties (2070-1600 BC), and lasted till the first appearance of vegetable oil from primitive pressing or extraction in the Western Zhou Dynasty (1046-771 BC). However, the variety of vegetable oils was very limited, i.e., most were sesame oils at that time. This situation got better in the Song (960-1279 AD), Ming (1368-1644 AD) and Qing (1612-1912 AD) dynasties, during which the development (e.g., oil-bearing plant cultivation, extraction and application) of vegetable oils flourished as never before. Indeed, during the Song period the gradual encouragement of Buddhism and vegetarianism initiated by temporal scholar-bureaucrats pushed these uses. Besides, the legendary Chinese namely Shennong experienced oils or fats infused with more than hundreds of herbal medicines as long ago as $2800 \mathrm{BC}$. His oral traditions written between about $300 \mathrm{BC}$ and $200 \mathrm{AD}$ had been collected, sorted out and edited in "Divine Farmer's Materia Medica" [7]. From this codex to the following classic "Compendium of Materia Medica" written by Li Shizhen (1518-1593) [8], the application of infused oils had gone through a thousand years' development and evolvement. Until now, the acupuncture and moxibustion assisted by oils infused with medicinal plants have still shown their miraculous effectiveness in traditional Chinese medicine.

Nowadays, vegetable oils play an important role in our ordinary diet, consumed directly in their refined or virgin forms, or via many food industrial products. Such oily products could also be used as ingredients or components in many other fields such as cosmetics, nutraceuticals, paints, lubricants and biodiesel. Therefore, the restudy of vegetable oils as alternative solvents in the 21st century will prompt the development of efficient strategies for their promising future applications such as extraction, purification and formulation.

\section{Vegetable Oils Are Not Only Triglycerides}

\subsection{Major Components in Vegetable Oils}

Vegetable oils are usually produced from plant seeds or fruits (e.g., rapeseed, sunflower, olive, etc.), simply by pressing and/or solvent extraction. They are considered nonpolar and lipophilic systems whose composition is highly variable and complex, depending on their origin, quality and producing methods. Vegetable oils have a relatively high flash point, a selective dissolving power and an attractive price $(\approx 0.5-5 € / \mathrm{kg})$ [9]. 
Triglycerides (Figure 1), which are composed of three fatty acid molecules esterified to one glycerol molecule, are the main building blocks of vegetable oils (95-98\%). The characteristics of triglycerides are determined by the types, proportions and positions of fatty acids on the glycerol backbone. The fatty acid composition of triglycerides in vegetable oils varies depending on varieties, cultivations, agronomic, and climatic conditions. Typically, even-numbered carbon atoms dominate the fatty acid chains' length in vegetable oils due to their bio-syntheses pathways. According to the saturation degree of fatty acids, they can be generally classified into saturated, mono- and poly-unsaturated fatty acids, which may have different configurations, resulting in different physical and chemical properties.

\section{Major components in vegetable oils}

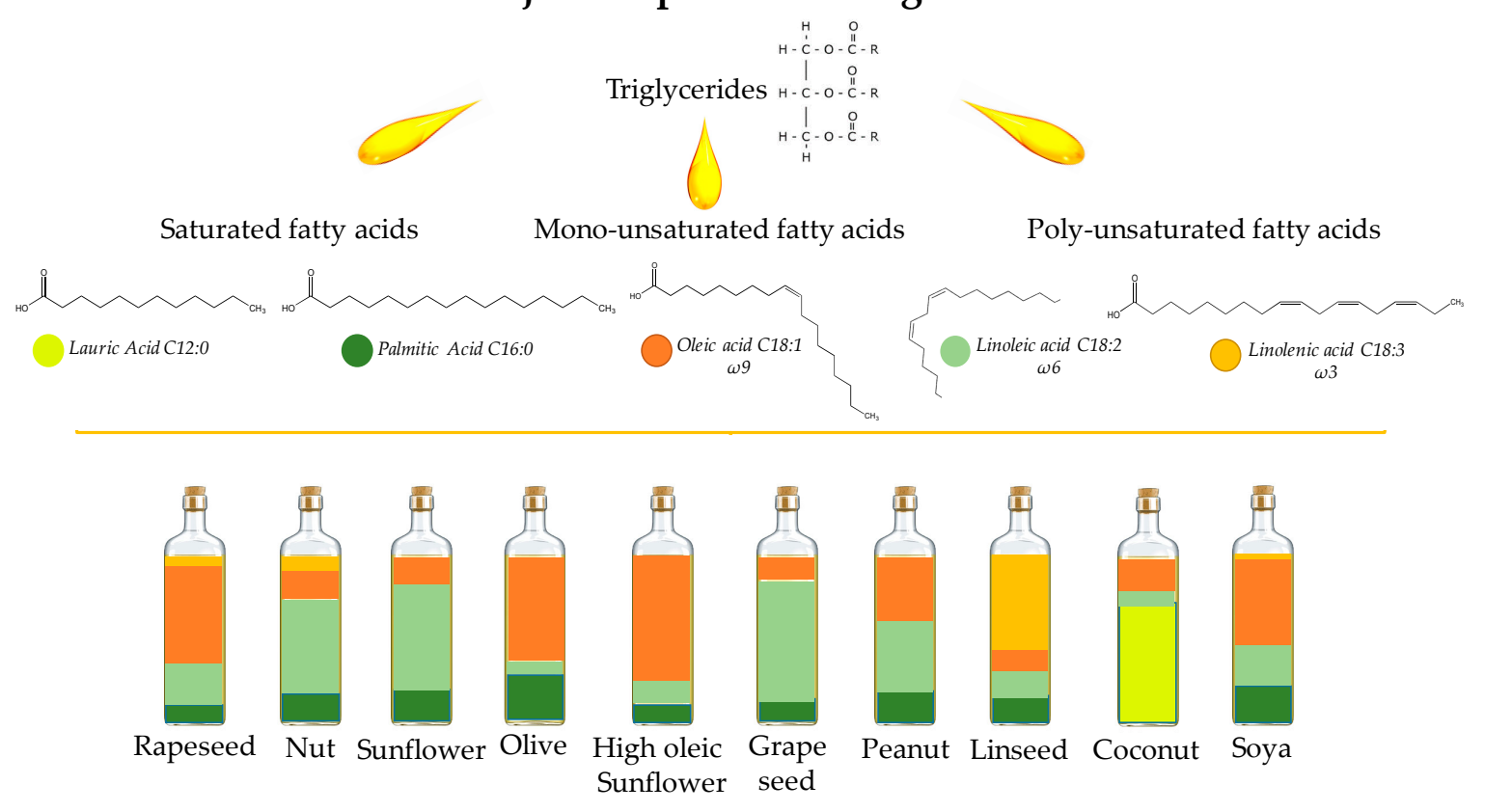

Figure 1. Major components in different vegetable oils.

\subsection{Minor Components in Vegetable Oils}

In addition to triglycerides, the presence of minor components (less than $5 \%$ ) in vegetable oils (Figure 2) cannot be ignored due to their interesting biological properties and nutritional values for pharmaceutical and nutraceutical industries, particularly in virgin oils [10,11]. They can be divided into two types: glycerolipids such as mono- and diglycerides, phospholipids, and non-glycerolipids including sterols, tocopherols/tocotrienols, free fatty acids, vitamins, pigments, proteins, phenolic compounds, water, etc. [12,13]. Although some undesirable minor components must be removed by most consumers and food manufacturers during the refining processes, there is no completely efficient and selective process, which will give rise to consequent colloidal structures formed by residual minor components in oils [14].

\subsubsection{Mono- and Di-Glycerides}

Partial glycerides, i.e., mono- and diglycerides, are mono- or diesters of glycerol with fatty acids (Figure 2), which are well known for their emulsifying properties. They are authorized food additives (E471), which can be obtained by partial hydrolysis of triglycerides during the extraction of vegetable oils. They are naturally present in virgin oils due to the action of endogenous lipases in fruits or oilseeds. The enzymatic hydrolysis leads to the formation of both partial glycerides and free fatty acids, in which partial glycerides account for 1-6 wt \% depending on oil types, for instance, the concentration of di glycerides ranges from 1 to $2.8 \%$ in the virgin olive oil and monoglycerides present at much lower levels (less than $0.25 \%$ ) [15]. The content of diglycerides in olive and palm oils 
is higher than that in virgin oils. Moreover, the neutralization and washing stages in the oil refining processes cannot eliminate partial glycerides in their refined forms. Mono- and diglycerides are amphiphilic molecules due to the presence of free hydroxyls, which give them a certain hydrophilicity with a hydrophilic-lipophilic balance (HLB) of about 3.4-3.8 and 2-5, respectively [16,17].

\section{General Composition of oil}

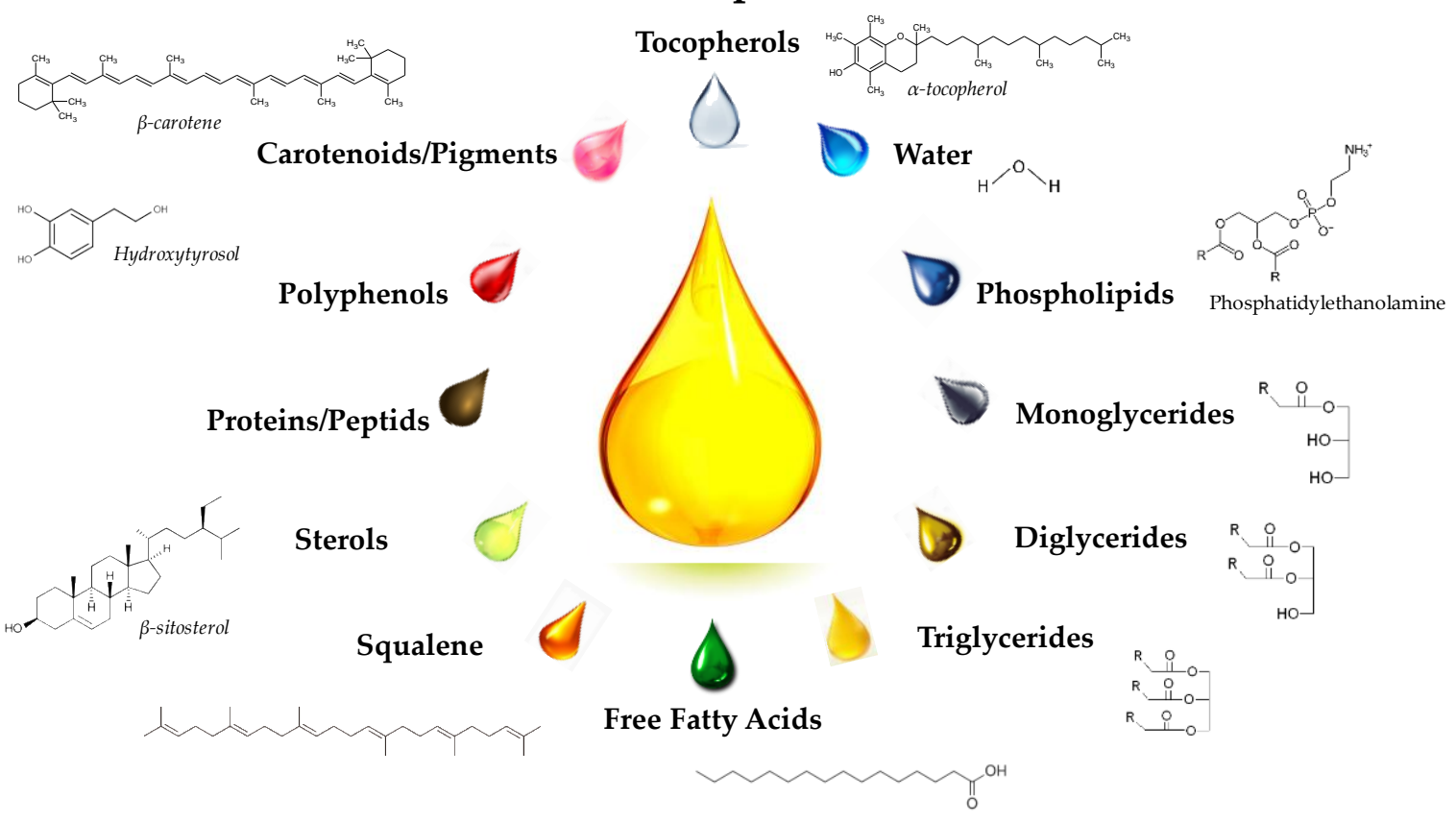

Figure 2. Minor components in vegetable oils.

\subsubsection{Phospholipids}

Phospholipids are considered polar lipids present in plant cell membranes, which co-extract with neutral triglycerides during squeezing or solvent extractions of both seeds and waste virgin oils using hexane. The main plant sources are soybean, rapeseed and sunflower. Most phospholipids are removed in the degumming step of the oil refining process in order to avoid foaming or browning during technological processing operations for edible oil uses. Phospholipids consist of a glycerol backbone, two fatty acids and one polar phosphate group associated itself with an amino alcohol (choline, ethanolamine, serine) or a sugar (inositol) as shown in Figure 2. Lecithins (phosphatidyl choline) are authorized food additives (E322) with wide applications, specifically in baking industry. This feature is because of their significant surfactant effect $(\mathrm{HLB} \approx 2-8)[16,18]$. Moreover, lamellar structures can be formed in the presence of phospholipids and other surface active compounds such as sterols, which are hard to characterize.

\subsubsection{Free Fatty Acids}

Free fatty acids are generated from the hydrolysis of triglycerides or phospholipids. They are usually eliminated during deodorization and physical refining processes due to their impacts on foaming and the smoke point of oils. Normally, virgin and refined vegetable oils or fats have free fatty acid contents of less than $5 \%$ and $0.1 \%$, respectively. However, their contents are higher when oils have high mono- and diglyceride percentages. Free fatty acids with a low HLB value of approximately 1.0 can assist the formation of reverse micelles so as to stabilize water-in-oil emulsions. Most fatty acids of natural origin have an alkyl chain comprising between 4 (C4) and 22 (C22) carbon atoms. The most common unsaturated fatty acids are C16 and C18. Short or medium chain fatty acids are normally 
recognized below these lengths whereas fatty acid chains with more than 18 carbons are often deemed to be long chain fatty acids [19].

\subsubsection{Sterols}

Apart from the very low content of cholesterol in vegetable oils, plant sterols, namely phytosterols, are not only some of the important minor compounds with considerable biological activities [20,21], but also the predominant compounds in the unsaponifiable fraction of vegetable oils. In general, $\beta$-sitosterol is the most abundant phytosterol in vegetable oils, along with variable amounts of other sterols (e.g., stigmasterol, campesterol, $\Delta^{5}$-avenasterol, brassicasterol, etc.) depending on the oil type [22]. Phytosterols are affected by several oil refining processes, in which deodorization can significantly reduce the total sterols due to distillations and esterifications of free sterols [11]. Since phytosterols are rather hydrophobic and poorly soluble in fats, they are usually esterified to make them liposoluble for easily processing handling in the food industries [23].

\subsubsection{Tocopherols and Tocotrienols}

Tocopherols and tocotrienols are well-known vitamin E compounds, which are vital for enhancing the oxidative stability of vegetable oils because of their strong inhibitory effects against lipid oxidation [24,25]. Naturally, tocopherols are presented as free alcohols while tocotrienols are in esterified forms [26]. There are four common types of tocopherols and tocotrienols $(\alpha, \beta, \gamma$ and $\delta)$, in which the number and the position of methyl groups on chromanol skeletons are different. The content of tocopherols and tocotrienols in different types is dependent on the oil type, which may also be influenced by their unintentional removal during the oil refining, especially in the deodorization $[27,28]$.

\subsubsection{Water}

A water content of less than $0.05 \%$ is generally controlled in commercial vegetable oils, which may change during preservation periods after opening as moisture absorption or loss happen according to the storage environment [29]. Since water is known for its immiscibility with oils, it can probably provide oil-water interfaces in vegetable oils where endogenous or exogenous surface active compounds with low HLB values migrate, preferably concentrate to form and to stabilize association colloids such as reverse micelles and lamellar structures [30]. These energetically preferential structures enable the coexistence of both hydrophilic and lipophilic compounds, which may inspire a novel solution for the extraction of water-soluble compounds in vegetable oils.

\subsubsection{Other Minor Compounds}

A wide range of phenolic compounds were reported at varying levels in vegetable oils (particularly in olive oils) depending on the oil type, ripeness, storage and processing conditions [31]. These polar compounds possessing free radical scavenging activity are important for the oxidative stability of the polyunsaturated fatty acids in vegetable oils. They tend to stay in the polar region of association colloids. Squalene is a triterpenoid hydrocarbon of thirty carbons, which presents in vegetable oils at a very low level [32]. It can be used in healthy foods and its hydrogenated form can be applied as a moisturizing agent in cosmetics. Pigments such as carotenoids in most virgin oils appear as a conjugated system with alternated double bonds in a long chain of forty carbons. They can be classified in nonpolar (e.g., $\alpha$ - or $\beta$-carotene and lycopene) and more polar carotenoids with oxygen at one or both end groups. Chlorophylls usually mask the colour of carotenoids in freshly pressed virgin oils, whose variable contents are determined by the oilseed maturity and the oil extraction method. Furthermore, the presence of proteins and peptides has also been investigated as minor components in virgin oils, which has attracted increasing concerns on the stability and the allergenicity of oils $[33,34]$. Besides, trace quantities of other components such as metals, hydrocarbons and amphiphilic lipid oxidation products are deleterious to oil quality so that they should be reduced to the minimum [22]. 


\section{Why Choose Vegetable Oils as Alternative Solvents?}

Although no official standards exist so far for the alternatives to petroleum-based solvents, the ideal properties of a green solvent to minimize environmental impacts during its complete life cycle have been summarized [35]. These bio-sourced or agro-based solvents should be non-volatile, safe, easy to regenerate and economically viable. Most importantly, they must have considerable dissolving power and selectivity. Hence, vegetable oils may have the potential of being a green alternative solvent due to their good consistency with ideal solvent properties.

Empirical infusion or maceration of medicinal and aromatic plants in vegetable oils as solvents dates back to ancient civilizations as already mentioned. In recent years, edible commercial vegetable oils have been successfully enriched or aromatized with bioactive compounds from herbs, spices or other plant materials in order to improve their nutritional values and organoleptic qualities, and to prolong shelf-life as well. The resulting oils can be defined as "flavoured oil" or "gourmet oil" named as the plant extracted. As the consumption of these products has drawn more interest due to their particular capacities for the prevention of diseases through a healthy diet, their versatility, convenience, and wide range of tastes have made them diffuse rapidly among traditional and non-traditional consumers across many countries in the world. Therefore, it is meaningful to explore more on their characteristics and applications as they are gaining an increasing popularity in diets, which can help to establish a sound labelling standard for strict regulations [36]. Nowadays, various enriched or aromatized oils are available in the market as seasonings. Moreover, considering that the solvent is often the major ingredient of a formulation, a reaction, or an extraction [37], vegetable oils are excellent alternatives for the substitution of petroleum solvents, such as hexane, in the extraction of bioactive compounds, and finally, they allow a better integration in the formulation of products. Table 1 shows different applications of various vegetable oils as solvents in natural product extractions, enriched oil preparations, and the formulation of products with applications in food and cosmetic industries.

As summarized above, most laboratory studies have proved the good dissolving power of vegetable oils, as well as better organoleptic quality and oxidative stability of their enriched forms. Since using vegetable oils as solvents in the direct extraction of carotenoids from shrimp by-products and microalgae has been successfully applied in several studies $[38,45,48-50,53]$, vegetable oils have proved their effectiveness in retaining high concentration of carotenoids under optimal conditions without any loss or degradation of carotenoids, or changes in the fatty acid profiles of the oil. Moreover, vegetable oils are usually enriched or flavoured with antioxidants or aromatic extracts from plants or by-products, which are obtained by means of traditional (infusion, one-step solvent extraction, etc.) or innovative methods such as ultrasound and supercritical $\mathrm{CO}_{2}$ using petroleum-derived organic solvents. This is consistent with a previously reported finding indicating that vegetable oil was a remarkably good solvent for a wide variety of food aroma compounds $[67,68]$. Although these organic solvents have been evaporated afterwards in enriched oils, it has also drawn an increasing concern on their safety in food-related applications and environment. In addition, the selectivity of vegetable oils is dependent on their types and components inside, resulting in variable extraction efficiency and enrichment factors. For vegetable oil solvents targeting to six major aroma extracts (i.e., linalool, estragole, eucalyptol, trans-anethole and limonene) from basil, refined sunflower oils was theoretically and experimentally proven as the most suitable solvent among ten vegetable oils [68]. Notwithstanding, such sunflower oil was not the optimal in the extraction of phenolic compounds from olive leaves as compared to its virgin form and several other vegetable oils like avocado, flaxseed and castor oils [69]. The extraction yield of total phenolic compounds was found to be more related to the type of vegetable oils and endogenous amphiphilic minor compounds rather than the polyunsaturated degree of vegetable oil triglycerides. 
Table 1. Applications of vegetable oils as solvents.

\begin{tabular}{|c|c|c|c|c|}
\hline Oil Types & Materials & Extracts & Experimental Remarks & Reference \\
\hline Soy oil & Crawfish waste & Astaxanthin & $\begin{array}{l}\text { Maximal pigment extraction and oil recovery was obtained from a 1:1 a ratio of oil to } \\
\text { crawfish waste. }\end{array}$ & [38] \\
\hline $\begin{array}{l}\text { Mixture of virgin and } \\
\text { refined olive oil }\end{array}$ & $\begin{array}{l}\text { Dry oregano, mature garlic bulbs } \\
\text { and rosemary leaves }\end{array}$ & Essential oils & $\begin{array}{l}\text { The flavoured oil with dry oregano and rosemary ( } 2 \mathrm{wt} \% \text {, dark, nitrogen, } 30 \mathrm{~min}, \\
\text { stirring) are beneficial to organoleptic quality and shelf-life while that with garlic }\left(5: 1^{\text {a }} \text {, }\right. \\
24 \mathrm{~h}, 25^{\circ} \mathrm{C} \text {, stirring) did not improve the storage stability. }\end{array}$ & [39] \\
\hline Sunflower oil & $\begin{array}{l}\text { Air-dried, powdered } \\
\text { Lamiaceae plants }\end{array}$ & Antioxidants & $\begin{array}{l}\text { Enriched oils contain } 0.1 \sim 0.5 \% \text { of organic solvent extracts, in which Satureja hortensis L. } \\
\text { ethanol extracts performed the best in oil stabilization. }\end{array}$ & {$[40]$} \\
\hline Olive oil & Rosemary, dry oregano & Phenolic compounds & $\begin{array}{l}\text { Total phenol content increased } 1.7 \text { and } 3.5 \text { times in rosemary and oregano gourmet oils } \\
(5 \mathrm{wt} \%, 24,48,72 \mathrm{~h} \text { agitation, dark), which have superior oxidative stability and } \\
\text { consumer acceptability to the origin oil. }\end{array}$ & [41] \\
\hline Vegetable oils & $\begin{array}{l}\text { Olive fruits, fruit particles } \\
\text { or residues }\end{array}$ & Phenolic compounds & $\begin{array}{l}\text { Mixture of oils with olive fruit materials and acids. Preferable conditions are } 10: 1^{\mathrm{a}} \sim 10: 3 \\
\mathrm{a}, 0.5 \sim 5 \mathrm{wt} \% \text { acid addition in oil-olive fruits mixtures, } 90 \sim 100^{\circ} \mathrm{C}, 90 \mathrm{~min} .\end{array}$ & [42] \\
\hline Olive oils & Olives & Flavouring agents & $\begin{array}{l}\text { A crushing and malaxation process at } 10 \sim 50^{\circ} \mathrm{C} \text { yielded flavoured oils with better } \\
\text { antioxidant activity and high flavour stability. }\end{array}$ & [43] \\
\hline Extra virgin olive oil & $\begin{array}{l}\text { Mentha piperita L. and } \\
\text { Thymus mastichina L. }\end{array}$ & Essential oils & $\begin{array}{l}\text { Enriched with steam-distilled essential oils. A high level }(0.008 \mathrm{mg} / \mathrm{kg}) \text { of Thymus } \\
\text { essential oil performed best in sensory test but Mentha essential oil must be kept at } \\
\text { a low level }(0.002 \mathrm{mg} / \mathrm{kg}) \text {. }\end{array}$ & [44] \\
\hline Vegetable oils & Shrimp waste (Panaeus indicus) & Carotenoids & $\begin{array}{l}\text { The carotenoid extraction using refined sunflower oil yielded higher than other oils } \\
\text { under optimized conditions }\left(2: 1^{\text {a }}, 150 \mathrm{~min}, 70^{\circ} \mathrm{C}\right) .\end{array}$ & {$[45]$} \\
\hline Virgin olive oil & $\begin{array}{l}\text { Dried hot pepper, garlic, oregano } \\
\text { and rosemary }\end{array}$ & Aromatic compounds & $\begin{array}{l}\text { Flavoured oils with spice oily extracts }\left(5: 1^{\mathrm{a}}, 25^{\circ} \mathrm{C} \text {, dark, daily shaking) improved the }\right. \\
\text { oil stability. Tasters were able to distinguish among addition levels, and oils flavoured } \\
\text { with } 20 \mathrm{~g} / \mathrm{L} \text { of rosemary, } 40 \mathrm{~g} / \mathrm{L} \text { of hot pepper, } 40 \mathrm{~g} / \mathrm{L} \text { of oregano and } 30 \mathrm{~g} / \mathrm{L} \text { of garlic } \\
\text { were preferred at the end of the storage. }\end{array}$ & [46] \\
\hline $\begin{array}{l}\text { Palm, olive \& } \\
\text { sunflower oils }\end{array}$ & Olive leaf (Olea europaea) & Phenolic compounds & $\begin{array}{l}\text { Enriched with methanol extract }\left(500: 1^{\mathrm{b}} \text { or } 250: 1^{\mathrm{b}}, 20 \text { min shaking, } 15 \text { min sonication). }\right. \\
\text { Polyphenol intake by consuming French fries pan-fried in the enriched oils was } \\
6 \sim 31 \text { times higher than French fries fried in commercial oils, which is dependent on the } \\
\text { frying oil type. }\end{array}$ & {$[47]$} \\
\hline Refined edible oils & $\begin{array}{l}\text { Microalgae (Haematococcus } \\
\text { pluvialis) }\end{array}$ & Carotenoids & $\begin{array}{l}\text { Carotenoid stock solutions ( } 5 \mathrm{wt} \% \text { ) were prepared using acetone extract for oil } \\
\text { enrichment. Palm oil was effective in retaining } 90 \% \text { of astaxanthin at } 90^{\circ} \mathrm{C} \text { for } 8 \mathrm{~h} \\
\text { without any changes in its ester form. Carotenoid loss was significant }(60 \sim 90 \%) \text { without } \\
\text { changes in the fatty acid profile of the edible oils at } 120 \text { and } 1500^{\circ} \mathrm{C} \text {. }\end{array}$ & [48] \\
\hline Palm oil & $\begin{array}{l}\text { Giant tiger shrimp } \\
\text { (Panaeus mondon) }\end{array}$ & Astaxanthin & $\begin{array}{l}\text { Palm oil was used as solvents to extract carotenoids from shrimp waste }\left(6: 1^{\text {a }}\right) \text { at various } \\
\text { particle sizes and temperatures. }\end{array}$ & [49] \\
\hline
\end{tabular}


Table 1. Cont.

\begin{tabular}{|c|c|c|c|c|}
\hline Oil Types & Materials & Extracts & Experimental Remarks & Reference \\
\hline $\begin{array}{l}\text { Soybean, corn, } \\
\text { grapeseed and olive oils }\end{array}$ & $\begin{array}{l}\text { Microalgae } \\
\text { (Haematococcus pluvialis) }\end{array}$ & Astaxanthin & $\begin{array}{l}\text { Vegetable oils enriched directly with microalgae culture }\left(1: 1^{\mathrm{b}}, 25^{\circ} \mathrm{C}, 48 \mathrm{~h} \text {, stirring }\right) \text {, the } \\
\text { mean recovery yield was over } 87.5 \% \text {. }\end{array}$ & [50] \\
\hline Extra virgin olive oil & $\begin{array}{l}\text { Tunisian aromatic plants (thyme, } \\
\text { rosemary, lavender, basil, lemon } \\
\text { zests, white sage, garlic, menthe } \\
\text { and geranium) }\end{array}$ & Aromatic compounds & $\begin{array}{l}\text { The incorporation of some Mediterranean aromatic plants into olive oil relatively } \\
\text { helped to improve their thermal resistance and stability. This may be due to the } \\
\text { abundance of natural antioxidants, which were transferred into olive oils during the } \\
\text { maceration process. }\end{array}$ & [51] \\
\hline Refined corn oil & Citrus aurantium peel & Essential oil & $\begin{array}{l}\text { Flavoured oil }\left(8: 3^{\mathrm{a}}, 1 \mathrm{~h}, 20^{\circ} \mathrm{C}, 100 \mathrm{rpm}\right) \text { showed the highest total volatiles with } \\
\text { unchanged fatty acid composition. }\end{array}$ & [52] \\
\hline Flaxseed oil & $\begin{array}{l}\text { Shrimp by-product } \\
\text { (Litopenaeus setiferus) }\end{array}$ & Astaxanthin & $\begin{array}{l}\text { Stirring solid-liquid enrichment }\left(1: 1 w / w, 60 \mathrm{~min}, 60^{\circ} \mathrm{C}\right) \text { yielded oils with better } \\
\text { resistance to oxidation and temperature. By-products generated from shrimp peeling } \\
\text { operations are a good source of high quality astaxanthin, which can be used as natural } \\
\text { colorants and antioxidant ingredients in human food and other industrial applications. }\end{array}$ & [53] \\
\hline Virgin olive oil & Olive cakes & Phenolic compounds & $\begin{array}{l}\text { Enriched oils with extracts using different methods, in which oils with extracts from } \\
\text { vegetative water and solid residue showed better quality than that with extracts from } \\
\text { freeze-dried olive cakes. }\end{array}$ & [54] \\
\hline Virgin olive oil & Freeze-dried olive cakes & Phenolic compounds & $\begin{array}{l}\text { The enriched oil with extracts }(7 \mathrm{mg} / \mathrm{mL} \text { oil) of accelerated solvent extraction showed } \\
\text { better oxidative stability, longer shelf life and less peroxides. }\end{array}$ & [55] \\
\hline Refined sunflower oil & Olive pomace & Phenolic compounds & $\begin{array}{l}\text { Such enriched oil ( }\left(1: 1^{\mathrm{b}}, 30 \mathrm{~min}\right) \text { could decrease the degradation of lipidic components } \\
\text { of the unsaponifiable fraction so as to improve stability. }\end{array}$ & {$[56]$} \\
\hline Corn oil & Thyme flowers (Thymus capitatus) & Pigments, antioxidants & $\begin{array}{l}\text { Flavoured oils ( } 8: 1 \text { a }, 25 \text { min agitation) showed improved thermal stability after heating } \\
\text { than refined corn oil. }\end{array}$ & [57] \\
\hline High oleic sunflower oil & Olive pomace & Phenolic compounds & $\begin{array}{l}\text { The enriched oil with ethanolic extracts up to } 400 \mu \mathrm{g} / \mathrm{mL} \text { performed the best oxidation } \\
\text { resistance during the frying process. }\end{array}$ & [58] \\
\hline Refined edible oils & Olive pomace and leaves & Phenolic compounds & $\begin{array}{l}\text { Oils mixing with ethanolic extracts up to favoured concentration of } 200 \text { or } 400 \mu \mathrm{g} / \mathrm{mL} \\
\text { had similar profile to extra virgin olive oils. }\end{array}$ & [59] \\
\hline Virgin olive oil & Rosemary, thyme \& oregano & Antioxidants & $\begin{array}{l}\text { Enrichment under stirring }\left(20: 1^{\mathrm{a}}, 25^{\circ} \mathrm{C} \text { or } 35 \sim 40^{\circ} \mathrm{C}\right) \text { led to more efficient mass transfer } \\
\text { than conventional maceration. A greatest enrichment of rosmarinic acids in oils was } \\
\text { found for oregano. }\end{array}$ & [60] \\
\hline Canola frying oil & $\begin{array}{l}\text { Olive and hazelnut leaf, hazelnut } \\
\text { green leaf cover }\end{array}$ & Phenolic compounds & $\begin{array}{l}\text { Enriched with aqueous ethanolic extracts at } 200 \mathrm{ppm} \text { phenolic equivalence level } \\
\left(100^{\circ} \mathrm{C}, 8000 \mathrm{rpm}, 7 \mathrm{~min}\right) \text { to enhance thermo-oxidative stability without sensory } \\
\text { quality deterioration. }\end{array}$ & [61] \\
\hline
\end{tabular}


Table 1. Cont.

\begin{tabular}{|c|c|c|c|c|}
\hline Oil Types & Materials & Extracts & Experimental Remarks & Reference \\
\hline Sicilian virgin olive oil & $\begin{array}{l}\text { Sicilian olive samples from eight } \\
\text { different cultivars }\end{array}$ & Phenolic compounds & $\begin{array}{l}\text { Influence of olive variety and elevation of orchards on the phenolic compound content } \\
\text { of Sicilian virgin olive oils (VOOs) was investigated, as well as the effect of VOO } \\
\text { phenolic extracts on osteoblast cell growth using the human MG- } 63 \text { osteosarcoma cell } \\
\text { line. Olive oil phenolic content and its effect on human osteosarcoma cell proliferation } \\
\text { varied according to the type of cultivar and grove altitude. }\end{array}$ & [62] \\
\hline Olive oil & $\begin{array}{l}\text { Rubus species (Rubus ulmifolius, } \\
\text { Rubus idaeus, Rubus caesius, Rubus } \\
\text { saxatilis, from the group Rubus } \\
\text { ulmifolius preferably Rubus } \\
\text { ulmifolius frutticosus Schott.) }\end{array}$ & Phenolic compounds & $\begin{array}{l}\text { The invention relates to the use of an oily extract of plants of Rubus species and the } \\
\text { topical treatment of cutaneous and mucosal pathologies and skin lesions. The invention } \\
\text { further concerns a method for obtaining such extract through extraction in oils at } \\
\text { room temperature. }\end{array}$ & [63] \\
\hline Olive oil & $\begin{array}{l}\text { Polyphenol compounds extracted } \\
\text { from the olive cake }\end{array}$ & $\begin{array}{l}\text { Phenolic-rich extract } \\
\text { (oleuropein complex or } \\
\text { secoiridoids: } 89.4 \% \text {; } \\
\text { hydroxytyrosol, tyrosol and } \\
\text { phenyl alcohols (vanillic acid, } \\
\text { p-coumaric acid and vanillin) } \\
3.5 \% \text {; and flavonoids, } 6.0 \% \text { ), } \\
\text { obtained from the olive cake }\end{array}$ & $\begin{array}{l}\text { High-polyphenol content functional virgin olive oil (FVOO) enriched with its own } \\
\text { polyphenols, improved endothelial function in pre- and hypertensive subjects beyond } \\
\text { the effects observed after the intake of a standard virgin olive oil (VOO) with moderate } \\
\text { polyphenol content, in a postprandial randomised, cross-over, controlled trial. }\end{array}$ & [64] \\
\hline Corn oil & $\begin{array}{l}\text { Thyme dried flowers } \\
\text { (Thymus capitatus) }\end{array}$ & $\begin{array}{l}\text { Phenolic compounds, } \\
\text { antioxidants }\end{array}$ & $\begin{array}{l}\text { Antioxidant activities of the thyme-enriched oil were mainly due to the presence of } \\
\text { phenolic compounds such as thymol and hydrocarbons such as } \gamma \text {-terpinene and } \\
p \text {-cymene. The thyme-enriched oil could be considered as a new and natural source } \\
\text { of antioxidant. }\end{array}$ & [65] \\
\hline Virgin olive oil & Olive and thyme polyphenols & Phenolic compounds & $\begin{array}{l}\text { The effects of virgin olive oil (VOO) enriched with its own phenolic compounds (PC) } \\
\text { and/or thyme PC on the protection against oxidative DNA damage and antioxidant } \\
\text { endogenous enzymatic system (AEES) were estimated in } 33 \text { hyperlipidemic subjects } \\
\text { after the consumption of VOO, VOO enriched with its own PC (FVOO), or VOO } \\
\text { complemented with thyme PC (FVOOT). The sustained intake of a FVOOT improves } \\
\text { DNA protection against oxidation and AEES probably due to a greater bioavailability of } \\
\text { thyme PC in hyperlipidemic subjects. }\end{array}$ & [66] \\
\hline
\end{tabular}

${ }^{\text {a }}$ Oil to solid material ratio $(\mathrm{mL} / \mathrm{g}) ;{ }^{\mathrm{b}}$ Oil to liquid extracts ratio $(\mathrm{mL} / \mathrm{mL})$. 


\subsection{How to Select a Good Solvent?}

A solvent is defined as "a liquid that has the property to dissolve, dilute or extract other materials without causing chemical modification of these substances or itself. Solvents are able to implement, apply, clean or separate products" [70]. These compounds play an important role in great number of unit operations in chemistry and chemical engineering. In fact, nowadays there is no production process in perfume, cosmetic, pharmaceutical, food ingredients, nutraceuticals, biofuel or fine chemicals industries without a solvation step [71]. Solvents can be used as diluents or additives in paints and inks, as cleaning agents or solvents for syntheses and extractions. From a macroscopic point of view, a solvent is a continuum characterized by physical constants (e.g., boiling point, melting point, vapour pressure, relative permittivity, thermal conductivity, surface tension, density, viscosity, refractive index, etc.) [72], whereas from a microscopic point of view, it is a discontinuum that consists of individual solvent interacting molecules characterized by molecular properties (e.g., dipole moment, electronic polarizability, hydrogen bond donor or acceptor character, electron donor or acceptor character, etc.). These different properties are at the origin of solute/solvent interactions during the solvation process.

The problem with most commonly used solvents is their negative impacts on health, safety and environment (HSE) as most solvents currently available in the world market come from the petrochemical industry and are volatile organic compounds (VOCs), such as the example of hexane used for oil extraction. In 2009, the global market of chemical compounds represented around 100 billion dollars, in which only $3 \%$ of these chemicals were obtained from renewable resources, after chemical processing, fermentation or enzymatic conversion. This share is predicted to attain around $15 \%$ by 2025 , when the global market is estimated to reach 3000 billion dollars [73]. With the geopolitical environment (increased oil prices and decrease of reserves), societal demand for more sustainable products and the arrival of the new regulations and guidelines (e.g., $\mathrm{REACH}$, etc.), much interest has been generated to the development of new eco-friendly ways of replacing conventional solvents. In other words, alternatives to petrochemical solvents have to fulfill the principles of Green Chemistry.

Replacing one solvent by another does not necessarily mean eliminating all the hazards and issues related to the implementation of a process. Indeed, the modification of a process is generally associated with new risks. Precautions should therefore be taken into account in the selection of an alternative solvent as for physicochemical, environmental or sanitary criteria, the eco-compatibility of the process and the price of the solvent, but also techno-economic criteria related to the properties of the solvent like dissolving power and energy consumption [74]. The dissolving power is a key criterion that can be evaluated using various methods such as the Kauri-butanol index, Kamlet-Taft scale, or Hildebrand and Hansen solubility parameters (HSP), but also thanks to a much more powerful tool, COnductor like Screening MOdel for Real Solvents (COSMO-RS), that can be used as a real decision tool for the choice of alternative solvents (Figure 3). On the other hand, pharmaceutical companies such as GSK [75], Sanofi [76], AstraZeneca [77,78] and Pfizer [79] developed their own solvent selection guides that provide technical data and clear instructions for the development of more sustainable processes. This allows the involvement and commitment of industries in the investigation on greener alternative solvents and proves their concern for the integration of sustainable development approaches.

To sum up, an ideal alternative solvent must fulfill the following requirements: (a) does not emit VOC; (b) be of low toxicity for humans; (c) have a limited impact on environment (be eco-friendly); (d) be obtained from renewable resources; (e) have a high dissolving power; (f) be easy to recover; and ( $\mathrm{g}$ ) does not change the process set-up significantly. To this end, new technologies such as solvent-free methods, aqueous formulations or alternative solvents, appear to be good candidates. Among these solutions the use of greener solvents, such as bio-based solvents, constitutes one of the most important alternative routes for the substitution of petrochemical solvents. The term "sustainable" or "green" is used to describe different types of solvents including the ones that are produced from biomass feedstock and eco-friendly petrochemical-based solvents that are non-toxic and/or biodegradable [80]. 


\section{Decision tools support for solvent's selection}

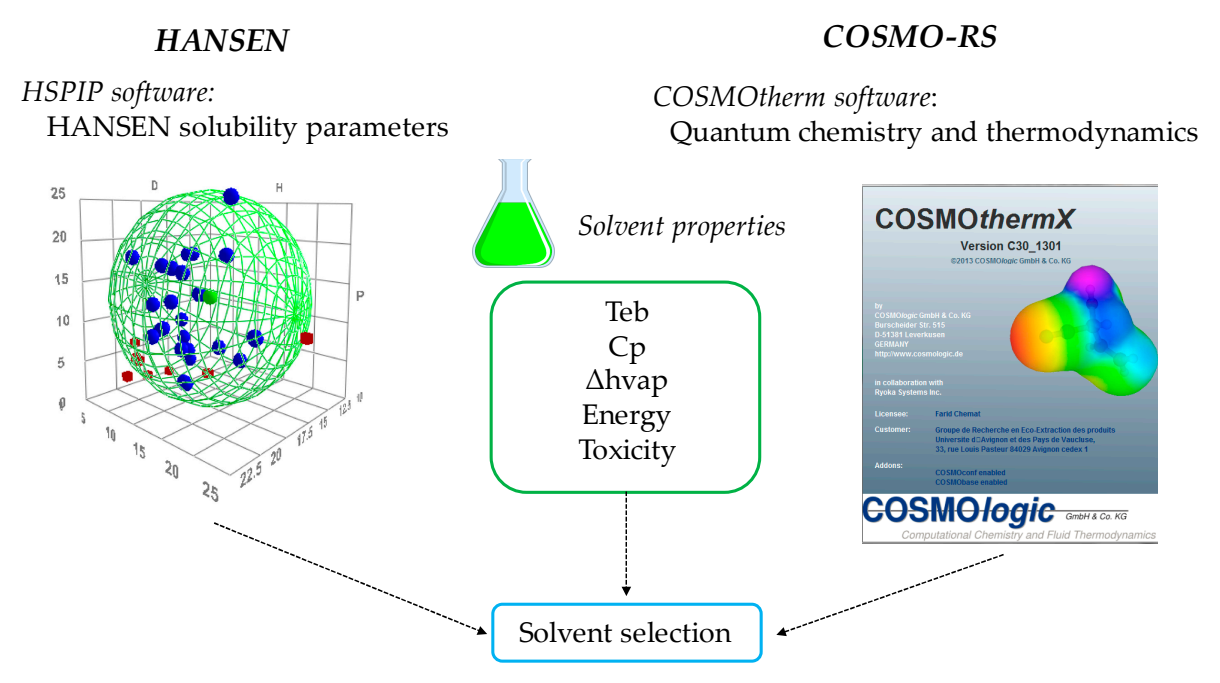

Figure 3. How to select a good and green solvent?

There are seven classes of solvents generally claimed as "green" solvents [81], including (1) bio-based solvents (from renewable resources), (2) eco-friendly (good HSE profile), (3) water (renewable and non-toxic), (4) liquid polymers (non-volatile, biocompatible, non-toxic), (5) fluorinated solvents (non-flammable and non-toxic), (6) ionic liquids/eutectic mixtures (non-volatile, thermally stable. e.g., imidazolium salts, choline acetate) and (7) supercritical fluids $\left(\mathrm{CO}_{2}\right.$, inert, recyclable, non-flammable, non-toxic). It is worth noticing that the greenness of some solvents is questionable with regard to toxicity (e.g., ionic liquids) or biodegradability (fluorinated solvents and silicones).

In this context, vegetable oils used as solvents belong to the bio-based solvent class, which have the advantage of offering a positive impact on the environment and health (no emission of volatile organic compounds, biodegradable and non-toxic). Vegetable oils are non-polar lipophilic systems whose composition varies considerably according to their origins, quality and methods from which they were obtained. Commonly used in cosmetics or in food industry, they can also be applied to extraction field as for example to achieve bioactive phytochemicals from natural resources. Vegetable oils have successfully been used as solvents for the extraction of carotenoids from by-products of crustaceans [38,49,53] or from fresh carrots [82], and also for the extraction of aromas from basil [68]. Likewise, vegetable oils have been enriched with diverse products such as aromas, polyphenols, antioxidants and pigments, which confer to the oils better oxidative stability and notable organoleptic qualities. Recently, extractions with vegetable oil solvents have been associated with various innovative technologies: ultrasound, microwave and supercritical $\mathrm{CO}_{2}$. The extraction of carotenoids from fresh carrots assisted by ultrasound showed similar yields to that obtained with hexane, under optimized conditions [82]. Sunflower oil as the solvent allowed the simplification of the extraction process, by the absence of the evaporation step or solvent separation. This greener technique also offered significant advantages in terms of cost, time and energy. Otherwise, supercritical carbon dioxide extractions of carotenoids using various vegetable oils as co-solvents have also been widely studied. The beneficial role of the addition of vegetable oil co-solvents was demonstrated, as it improved the solvation performance and prevented the degradation of target carotenoids during the extraction. In addition, a work performed by Chevereau [83] determined that using vegetable oils as solvents and microwave as the extraction method provided an improvement in the extraction efficiency of bioactive extracts without degradations or contaminations of the oil. The improved dissolving power (high yields, optimized organoleptic properties) of vegetable oils by association with ultrasound and microwave was also presented in the work of Rossignol-Castera [84]. As the application of vegetable oils as alternative solvents has emerged in many areas, a good investigation of various components in vegetable oils 
is necessary for better understanding their underlying dissolving mechanism, which could lead to a green strategy for extraction techniques.

\subsection{Can Nonpolar Vegetable Oils Be Good Solvents for Polar Antioxidants?}

Knowledge developed during the last two decades helped us to gradually find out that the effectiveness of antioxidants in the lipid oxidative inhibition is depending on both chemical reactions and physical molecular orientations, self-assembled microenvironments in particular. According to the "polar paradox" breakthrough $[85,86]$, polar or hydrophilic antioxidants with high HLB values are more effective in non-polar media such as vegetable oils with a low surface/volume (LSV) ratio whereas nonpolar or lipophilic antioxidants with low HLB values tend to be more effective in more polar media such as oil-water emulsions with a high surface/volume (HSV) ratio. This hypothesis was turned from an empirical observation into a putative theory thanks to the explanation by the interfacial phenomenon $[87,88]$. The previously believed assumption on oxidation in vegetable oils as homogeneous media was questioned because oil is more polar than air. Since polar antioxidants, amphiphilic molecules and trace amounts of water coexist in whatever vegetable oils, they will aggregate to form different types of colloidal associations (e.g., reverse micelle, lamellar structure, etc.), which are considered oxidation sites [22]. The polar antioxidants distributing at the oil-air interface are indeed preferentially located at the oil-water interface of colloids, hence perform more effective in oxidative inhibitions than nonpolar ones that are dissolved in the lipid phase (Figure 4). The polar paradox was found not applicable for the overall concentration range of antioxidants as more evidences have indicated a non-linear cut-off effect for nonpolar antioxidants that are more effective below a critical concentration than polar antioxidants in vegetable oils because the solubility effect outweighs the interfacial phenomena. The reversed trend occurred after this critical concentration is the polar paradox case, which depends more on the micellar effect [89].

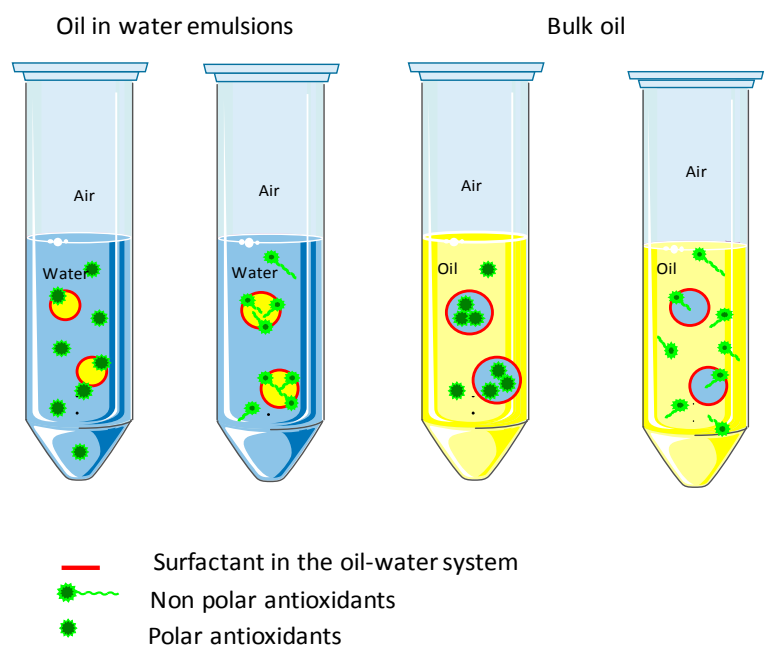

Figure 4. Polar paradox theory.

Paradoxes and inconsistencies are constantly emerging. Supramolecular chemistry as a new paradigm may shed light on lipid oxidation and antioxidant effectiveness now by reconsidering molecular shape, supramolecular interactions and the distribution of polar and nonpolar regions [90]. In vegetable oils, water inside or from atmosphere and other polar compounds are located in the core of reverse micelles. A depletion layer almost without surfactants exists next to the core and the outermost monolayer was comprised of surfactants, which solubility could be increased with the help of co-surfactants (e.g., short or medium chain alcohols, glycerol, sorbitol, etc.). These self-assembled micelles are considered as thermodynamically stable nano-reactors, which have different sizes and allow the dissolution of a desirable amount of polar and non-polar compounds [91]. 
Hydrophilic lipophilic balance (HLB) is empirically used to describe the antioxidant solubility in lipid systems. Endogenous or exogenous surfactants with low or intermediate HLB values, for instance, phospholipids, free fatty acids, mono- and diacylglycerides, are more favoured to form and to stabilize reversed micelles [22]. Traces of these minor compounds in virgin or refined vegetable oils play a vital role in micellization and further lipid preservation. Nonetheless, there are still other influencing factors (e.g., $\mathrm{pH}, \log \mathrm{P}$, double bond position in unsaturated fatty acids, acyl chain length, ionicity and packing parameter of surfactants, etc.) for antioxidant effects and micelle stabilization in lipid systems, among which water activity is of paramount importance.

Inspired by the paradoxical behaviour of polar antioxidants in bulk lipids, vegetable oils can not only be the solvents for the lipophilic antioxidants in light of the "like dissolve like" principle. The self-assembled micellization in vegetable oils may help to develop an in-site direct extraction of hydrophilic antioxidants [69], where extraction efficiency, selectivity and enrichment factors are variable depending on the oil type and composition, as well as surfactant type and dosage [92]. The spherical reverse micelles could be formed by a simply intentional addition of food-grade surfactants and proved by small angle X-ray scattering (SAXS). However, the appropriate dosage of surfactants should be further evaluated to make sure their critical micellization concentrations and interactions in a supramolecular microenvironment. Likewise, this novel extraction may provide a more efficient strategy for the lipid oxidative prevention in further formulations.

\subsection{Which Kind of Molecules Can Be Solubilized in Vegetable Oils?}

Determining the different molecules that can be solubilized into vegetable oils seems relatively easy if we know the polarity of the target molecules. However, there are some considerations in the prediction of the dissolving power of vegetable oils such as their supramolecular complexity, various extraction methods, target solute, acylglycerol and fatty acid composition, etc. Today, one way to predict the solubilization of one molecule into different solvents including vegetable oils, avoiding the waste of time in resorting to trial and error experiments, is the use of efficient predictive tools, among which the most powerful one is the COSMO-RS that we have currently paid particular attention on.

\section{COSMO-RS Approach}

The significant improvement in computational power and sophistication of recent algorithms led to the possibility to extensively use quantum descriptors of the solvent effect. Cartier et al. showed that quantum chemistry provides a more accurate and more detailed description of electronic effects than empirical methods [93]. Thanks to a combination of a dielectric continuum solvation model and a thermodynamic treatment of the molecular interactions, Klamt developed a general approach in which a solvent can be treated in the liquid state [94]. In the first step of the COnductor-like Screening MOdel, usually denoted as COSMO, the solute molecule is considered to be embedded in a cavity that is surrounded by a virtual conductor. In this environment the molecule induced a polarization charge density on its surface depicted on the $\sigma$-surface. During the quantum calculation, the solute molecule is converged to its energetically optimal state in the conductor with respect to its electron density and geometry. In the second step, with the extension RS for "Real Solvent", a combination of an electrostatic theory, COSMO-RS, with the statistical thermodynamics treatment of interacting surfaces is used. The spatial distribution of the polarization charge $\sigma$ of the molecule is then converted into a surface composition function ( $\sigma$-profile). This $\sigma$-profile provides information about the molecular polarity distribution (Figure 5).

The thermodynamics of molecular interactions is used to calculate the chemical potential of the surface segment ( $\sigma$-potential) using COSMOthermX program (version C30 release 14.10). The $\sigma$-potential (Figure 5) can be interpreted as the affinity between a solvent and the surface $\sigma$ via electrostatic interactions and hydrogen bonds. The part of the negative charge of the molecule is located on the right side (acceptor hydrogen bonds) with positive $\sigma$ values while the part of the positive charges is located on the left side (donor hydrogen bonds) with negative $\sigma$-values. Generally, the region 
$\sigma \pm 1 \mathrm{e} / \mathrm{nm}^{2}$ is considered to be non-polar or weakly polar. The $\sigma$-profile and the $\sigma$-potential are used to firstly interpret the affinity of the solvent for surface polarity, and then to understand the interaction between the solute compound and a list of solvents. The thermodynamic properties of the system could finally be estimated. In addition, the software COSMOthermX allows the calculation of the affinity between the solute and the solvent in terms of logarithm of the solubility in mole fractions $\left(\log 10\left(x \_s o l u b\right)\right)$. The logarithm of the best solubility (i.e., solute and solvent are miscible) is equal to 0 and all other solvents are predicted relative to the best solvent(s).

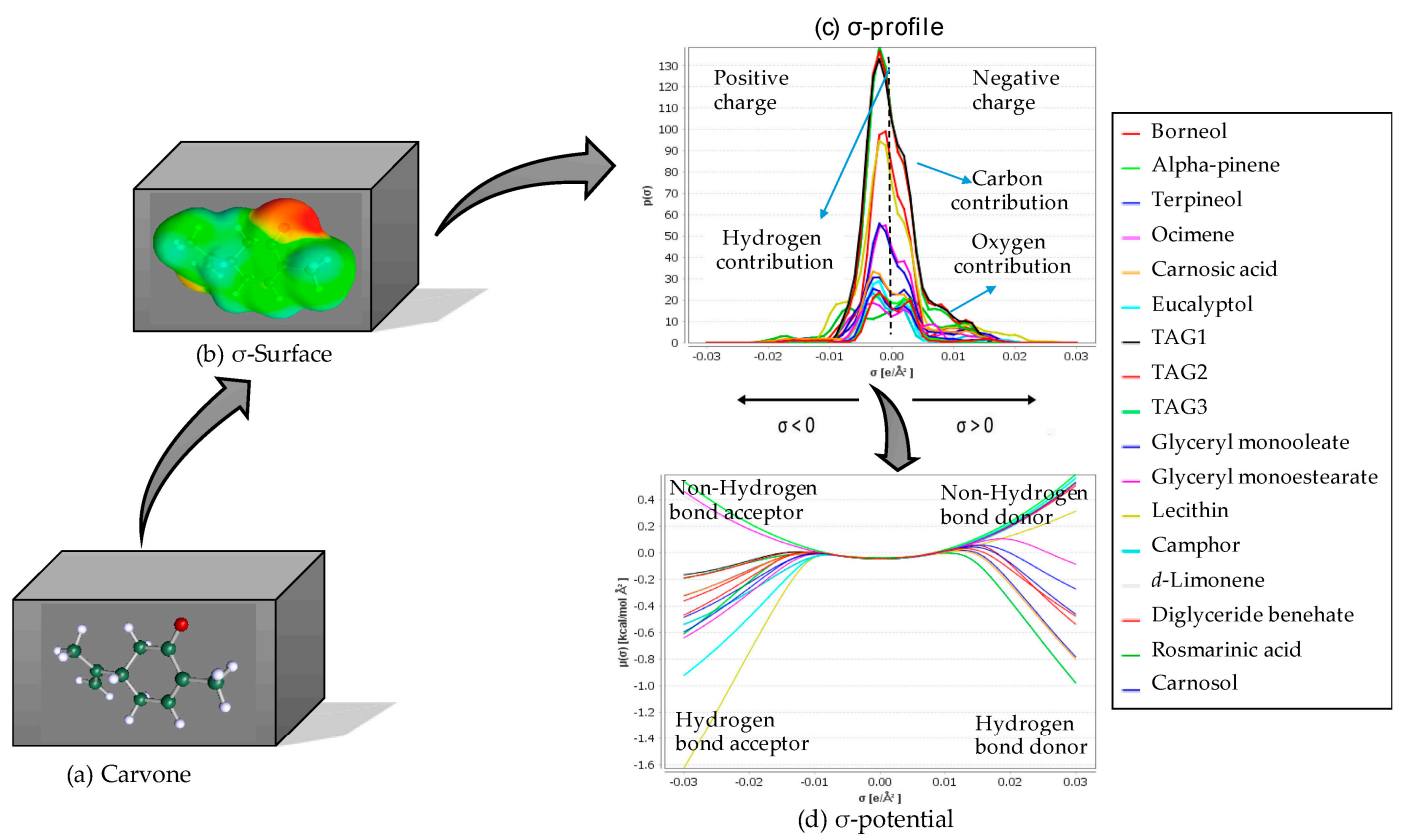

Figure 5. COSMO-RS to select ideal solvent for dissolving a suitable compound. (a) Carvone (solute molecule); (b) $\sigma$-surface; (c) energies of local surface interactions between $\sigma$-profiles of carvone and solvents; (d) $\sigma$-potentials of carvone and solvents.

Despite the fact that vegetable oils have been used as solvents in the extraction of natural compounds, as well as their enrichment with diverse bioactive compounds, predictive methods such as COSMO-RS have not been used to determine the potential of these alternative bio-based solvents. In this context, we have performed the simulation of the solubility of various bioactive products with different polarities in sunflower oils, from lipophilic $\beta$-carotene to hydrophilic compounds with higher polarity as antioxidants like hydroxytyrosol. In addition, we have also evaluated the relative solubility of these bioactive compounds in the sunflower oil with surfactants and conventional solvents such as $n$-hexane, ethyl acetate, acetone, ethanol and water. $n$-Hexane, the most commonly employed solvent in the extraction field, was used as the reference. The simulation results showed that the theoretical solubility of the bioactive compounds in general was better in sunflower oil or sunflower oil with $1 \% w / w$ of surfactant than in $n$-hexane. Li et al. performed a direct extraction of phenolic compounds from olive leaves using vegetable oils as solvents and food additives (soy lecithin, diglycerides, unsaturated or saturated mono glycerides) as surfactants [69]. The experimental results showed a significant difference on the extraction yield of phenolic compounds among various refined and unrefined oils, which were mainly dependent on their composition instead of the unsaturation degree of fatty acids. This work concluded that appropriate surfactant additions could significantly improve the extraction yield for refined sunflower oils, where the $1 \% \mathrm{w} / \mathrm{w}$ addition of glyceryl oleate was determined as the optimal. Furthermore, $5 \% w / w$ addition of lecithin performed the best in such enrichments compared with mono- and di-glycerides. The exception in the simulation results was with $\beta$-carotene, whose solubility prediction was slightly better in the reference solvent. However, experimental results have shown that vegetable oils are good solvents for the extraction of this sort of natural products. Sun and Temelli [95] carried out a comparison of conventional 
solvent extraction with supercritical $\mathrm{CO}_{2}\left(\mathrm{SC}-\mathrm{CO}_{2}\right)$ extraction using canola oil as the co-solvent to extract carotenoids from carrots. It was found that the yield of total carotenoids by $\mathrm{SC}-\mathrm{CO}_{2}$ extraction with $5 \%\left(w / w\right.$ of $\left.\mathrm{CO}_{2}\right)$ canola oil was higher than that by conventional solvent extraction using hexane or acetone. The triglycerides here can increase $\beta$-carotene solubility in supercritical $\mathrm{CO}_{2}$, and additionally, vegetable oils help to improve the stability of pigments [96]. Therefore, the use of different vegetable oils as co-solvents in $\mathrm{SC}-\mathrm{CO}_{2}$ is a new approach for carotenoids recovery with promising results [94,97-101]. Likewise, Li et al. applied sunflower oil as a substitute for organic solvents in carotenoids extraction from fresh carrots using an ultrasound-assisted extraction (UAE) process [82]. This procedure was compared with conventional solvent extraction (CSE) using hexane as the solvent. The results showed that the green UAE process using sunflower oil as the solvent gave the best yield of $\beta$-carotene in comparison with CSE.

\section{Innovative Techniques for Intensified Extraction Using Vegetable Oils as Solvents}

Bioactive compounds from plants, algae, yeast and fungi can be extracted by various classical extraction techniques such as maceration, solvent extraction, steam or hydrodistillation, cold pressing, squeezing, and others. Most of these techniques are based on the extracting power of different solvents and the application of heat and/or mixing. Nonetheless, the design of more efficient extraction processes that may address the requirements for process intensification (i.e., faster and more effective energy use, increased mass and heat transfer, reduced equipment size, reduction of processing steps and increase of yields and product quality) has been one of the main research topics in recent years. All safety, sustainability, environmental and economic factors are forcing laboratories and industries to turn to nonconventional technologies and greener protocols. Moreover, due to toxicity and the growing price of fossil resources, the replacement of petroleum-origin solvents is desirable. Consequently, in the last two decades, the use of efficient, innovative and intensified extraction techniques is amenable to automation such as widely used ultrasound, microwave and supercritical fluid assisted extraction. In addition, the combination of ultrasound with conventional Soxhlet extraction [102,103], Clevenger distillation [104] and innovative techniques [105-110] has been reported as well [111].

Due to the fact that several special phytochemicals are either destroyed or lost during distillation, or are very difficult to extract resulting in a low yield of essential oils, herbal infused oils are indispensable for obtaining such compounds. Therefore, the solvent property of vegetable oils and their applications with innovative techniques (e.g., ultrasound, microwave, supercritical fluids, etc.) have been explored in bioactive phytochemicals' extractions from natural bio-resources, which helped to achieve a greener extraction procedure and novel value-added end-products with great potential in food, nutraceutical and cosmetics industries. Table 2 presents some applications of innovative techniques for the extraction of different kind of compounds from various plant materials using vegetable oils as solvents or co-solvents to be enriched with bioactive compounds. In this context, the ultrasound-assisted extraction (UAE) based on Green Extraction and bio-refinery concepts using sunflower oil as the solvent has recently been designed for the extraction of carotenoids from fresh carrots. The extraction yield under optimized UAE conditions was similar to that of conventional extraction using hexane as the solvent [82]. Furthermore, this greener technique also offered significant benefits in terms of cost, time, energy and environment; and showed its potential for an industrial-scale application in relevant fields. In addition, supercritical carbon dioxide extractions of different carotenoids and derivatives using various vegetable oils as co-solvents have also been widely studied. The beneficial role of adding vegetable oils as co-solvent has been demonstrated to enhance the yield, and to avoid the degradation of the target carotenoids during the extraction [95,97,100,101,112]. Apart from this, Chevereau [83] has applied microwaves to improve the extraction efficiency of bioactive extracts in vegetable oils without lipid degradation and product contaminations. Furthermore, Rossignol-Castera [84] proposed a greener extraction procedure intensified by both microwaves and ultrasounds, which could improve the solvent power of oils in order to ensure a good reproducibility of produced extracts with high yields and optimal organoleptic properties. These novel developed techniques have already been put into real production on an industrial scale. 
Table 2. Innovative techniques applied in the extraction of bio-active compounds using vegetable oils as solvents.

\begin{tabular}{|c|c|c|c|}
\hline Technique & Matrix & Experimental Remarks & Reference \\
\hline \multirow{7}{*}{ Ultrasound } & $\begin{array}{l}\text { Olive leaves } \\
\text { (Olea europaea L.) }\end{array}$ & $\begin{array}{l}\text { Solid-liquid oil enrichment }\left(10: 1^{\mathrm{a}}, 20 \mathrm{~min}, 25^{\circ} \mathrm{C}\right) \text { assisted by ultrasound }(225 \mathrm{~W}, 50 \% \text { amplitude, duty cycle } 0.5 \mathrm{~s}) \text { produced edible oils } \\
\text { with better quality than non-ultrasonicated oils. }\end{array}$ & [113] \\
\hline & $\begin{array}{l}\text { Basil leaves } \\
\text { (Ocimum basilicum L.) }\end{array}$ & $\begin{array}{l}\text { Ultrasound-assisted aromatisation of } 1 \mathrm{~L} \text { of olive oil with fresh basil leaves of different amounts. The essential oil contained in the basil } \\
\text { leaves was directly extracted into the olive oil without any intermediate stage, which led to an aromatised olive oil in few minutes } \\
\text { compared to several hours required in the conventional maceration. }\end{array}$ & [114] \\
\hline & $\begin{array}{l}\text { Olive leaves } \\
\text { (Olea europaea L.) }\end{array}$ & $\begin{array}{l}\text { Olive oil enrichment with phenolic compounds (e.g., oleuropein) from olive leaves by ultrasonic maceration }\left(60 \mathrm{~W}, 16^{\circ} \mathrm{C} \text { and } 45 \mathrm{~min}\right) \text {. } \\
\text { The highest total phenolic content }(414.3 \pm 3.2 \mathrm{mg} \text { of oleuropein equivalent } / \mathrm{kg} \text { of oil), oleuropein }(111.0 \pm 2.2 \mathrm{mg} / \mathrm{kg} \text { of oil) and } \\
\alpha \text {-tocopherol ( } 55.0 \pm 2.1 \mathrm{~g} / \mathrm{kg} \text { of oil) concentrations obtained by optimized ultrasound-assisted extraction proved its efficiency } \\
\text { compared to the conventional solid-liquid extraction. }\end{array}$ & [115] \\
\hline & $\begin{array}{l}\text { Sea buckthorn pomace } \\
\text { (Hippophae rhamnoides) }\end{array}$ & $\begin{array}{l}\text { Ultrasound-assisted extraction (power } 0.67 \mathrm{~W} / \mathrm{g} \text { oil and } 35^{\circ} \mathrm{C} \text { ) has been used to greatly improve the direct enrichment of edible oils } \\
\text { (sunflower, rapeseed, olive, and soya) with carotenoids from sea buckthorn pomaces in terms of quantity and process time (from } 33.83 \\
\mathrm{mg} / \mathrm{L} \text { extract in } 90 \mathrm{~min} \text { obtained by conventional extraction to } 51.64 \mathrm{mg} / \mathrm{L} \text { extract in only } 20 \mathrm{~min} \text { by ultrasound). }\end{array}$ & [116] \\
\hline & Carrot (Daucus carota L.) & $\begin{array}{l}\text { Ultrasound-assisted extraction (carrot/oil ratio } 2: 10,22.5 \mathrm{~W}, 40^{\circ} \mathrm{C} \text { and } 20 \mathrm{~min} \text { ) using sunflower as alternative solvent to hexane } \\
\text { obtained highest } \beta \text {-carotene yield ( } 334.75 \mathrm{mg} / \mathrm{L} \text { ) in } 20 \mathrm{~min} \text {, while conventional solvent extraction obtained a similar yield } \\
(321.35 \mathrm{mg} / \mathrm{L} \text { ) in } 60 \mathrm{~min} \text {. }\end{array}$ & [82] \\
\hline & $\begin{array}{l}\text { Carrot residue (obtained } \\
\text { after juice extraction) } \\
\text { (Daucus carota } \text { L.) }\end{array}$ & $\begin{array}{l}\text { Extraction using ultrasonic horn }\left(20: 0.3^{\mathrm{a}}, 100 \mathrm{~W}, 50 \mathrm{~min}, 50^{\circ} \mathrm{C}\right) \text {, the maximum extraction yield of } \beta \text {-carotene was } 83.32 \% \text { while that } \\
\text { was } 64.66 \% \text { when using ultrasonic bath. }\end{array}$ & [117] \\
\hline & $\begin{array}{l}\text { Pomegranate peels } \\
\text { (Punica granatum L.) }\end{array}$ & $\begin{array}{l}\text { Sunflower and soy oil were used as alternative solvents to study the effect of various parameters on the yield between ultrasound and } \\
\text { conventional extraction, in which the optimal conditions for achieving maximum yield of carotenoids from pomegranate peels were } \\
10: 1^{\mathrm{a}}, 30 \mathrm{~min}, 51.5^{\circ} \mathrm{C}, 58.8 \% \text { of amplitude level and sunflower oil solvent. }\end{array}$ & [118] \\
\hline \multirow[b]{2}{*}{$\begin{array}{l}\text { Microwave } \\
\text { coupling } \\
\text { ultrasound }\end{array}$} & $\begin{array}{l}\text { Vegetables, herbs, spices } \\
\text { or fruits }\end{array}$ & $\begin{array}{l}\text { Time-saving aromatizations of olive oil with different compounds from various plants were improved by ultrasound and microwave. } \\
\text { The resulting flavoured oils are increasingly appreciated by European consumers. }\end{array}$ & [34] \\
\hline & $\begin{array}{l}\text { Sweet Pepper } \\
\text { (Capsicum annuum) }\end{array}$ & $\begin{array}{l}\text { Compared to traditional infusion or maceration }\left(10: 1^{a}, 7 \text { days), For the ultrasonic treatment, samples of olive oil were prepared by }\right. \\
\text { adding } 10 \% \text { and } 20 \% \text { dried chili pepper and subjected to ultrasound-extraction for } 10 \text { or } 20 \text { min. For microwave extraction, samples } \\
\text { were added with } 20 \% \text { chili powder and treated for } 10,30 \text { or } 60 \mathrm{~s} \text {. The production of flavored olive oils by using technologies such as } \\
\text { microwave and ultrasound-extraction could allow the production of high quality oils, with fast and cost-effectively methods. }\end{array}$ & [119] \\
\hline \multirow{3}{*}{ Microwaves } & Aromatic plants & A patented method for the extraction of aromas from aromatic plants using microwave is disclosed. & [83] \\
\hline & Olive leaf & $\begin{array}{l}\text { Liquid-liquid enrichment with microwave phenolic extract }\left(1: 1^{a}, 15 \mathrm{~min}, 600 \text { units } / \mathrm{min}\right) \text {. Olive oil was the most enriched. Enrich oils } \\
\text { obtained a better taste quality. }\end{array}$ & [120] \\
\hline & Olive waste (orujo) & $\begin{array}{l}\text { Solid-liquid and liquid-liquid oil enrichments }\left(1: 1^{a}, 30 \mathrm{~min}\right) \text { with dilutions of microwave phenolic extracts. The phenol distribution } \\
\text { factor increases with high level of unsaturated fatty acids whereas high-saturated fatty acid content decreases this factor. }\end{array}$ & [121] \\
\hline
\end{tabular}


Table 2. Cont.

\begin{tabular}{|c|c|c|c|}
\hline Technique & Matrix & Experimental Remarks & Reference \\
\hline & Fresh vegetable materials & $\begin{array}{l}\text { The present invention relates to a method for obtaining an oily extract of plants from plant material comprising the steps of mixing } \\
\text { the plant material with a fat, heating (microwave at } 0.1 \text { to } 5 \mathrm{~W} / \mathrm{g} \text { of oil and plant material mixture) said mixture and recovery of the } \\
\text { oily extract. The present invention finds particular application in the field of the production of special extracts, scent extracts, extracts } \\
\text { perfuming, supply of raw materials, olfactory raw materials, active ingredients, for example in cosmetics and/or dermatology. }\end{array}$ & [122] \\
\hline & Daylily (Hemerocallis fulva) & $\begin{array}{l}\text { The invention relates to the use of an oily composition comprising a lipophilic extract of daylily as an active ingredient for the } \\
\text { preparation of a topical cosmetic composition intended to improve complexion radiance and/or to even skin tone, to a } \\
\text { non-therapeutic cosmetic skin treatment method using such a cosmetic composition. The extract is obtained by the technique of } \\
\text { heating by microwaves using avocado oil and rose hip oil. }\end{array}$ & [123] \\
\hline \multirow{6}{*}{$\begin{array}{l}\text { Supercritical } \\
\text { fluids }\end{array}$} & $\begin{array}{l}\text { Tomato } \\
\text { (Solanum lycopersicum L.) }\end{array}$ & $\begin{array}{l}\text { Extraction of lycopene from tomato using SC- } \mathrm{CO}_{2} \text { extraction in the presence of vegetable oil as co-solvent. The pre-treatment of raw } \\
\text { material (drying, grinding and screening) is necessary in order to obtain significative yields of the extractable lycopene. The operative } \\
\text { parameters (flow, time, pressure, etc.) are also crucial for better yields and the best operative conditions found are the following: } \\
\text { pressure } 450 \text { bar, temperature } 65-70{ }^{\circ} \mathrm{C}_{1} \mathrm{CO}_{2} \text { flow rate } 18-20 \mathrm{~kg} \mathrm{CO} \mathrm{CO}_{2} / \mathrm{h} \text {, average particle sizes of the material of about } 1 \mathrm{~mm} \text {, presence } \\
\text { of a vegetable oil as co-solvent (about } 10 \% \text { ). }\end{array}$ & {$[97]$} \\
\hline & $\begin{array}{l}\text { Red pepper } \\
\text { (Capsicum frutescens L.) }\end{array}$ & Enriched oils with supercritical $\mathrm{CO}_{2}$ extracts $(0.5 \mathrm{wt} \%)$ at low pressure and velocity $\left(40^{\circ} \mathrm{C}, 10 \mathrm{~min}\right)$ performed stable. & [124] \\
\hline & Carrot (Daucus carota L.) & $\begin{array}{l}\text { Employing canola oil as a continuous co-solvent in } \mathrm{SC}^{-} \mathrm{CO}_{2} \text { extraction is a novel and efficient technique for the recovery of } \\
\text { carotenoids from natural materials. }\end{array}$ & [95] \\
\hline & $\begin{array}{l}\text { Microalgae } \\
\text { (Haematococcus pluvialis) }\end{array}$ & $\begin{array}{l}\text { Soybean oil and olive oil used as co-solvents were investigated for } \mathrm{SC}-\mathrm{CO}_{2} \text { extraction of astaxanthin from } \mathrm{H} \text {. pluvialis. The result of } \\
\text { the } \mathrm{SC}-\mathrm{CO}_{2} \text { extraction of astaxanthin with the presence of } 10 \% \text { by volume olive oil showed the higher increase in the amount of } \\
\text { astaxanthin extracted. }\end{array}$ & [112] \\
\hline & Marigold (Tagetes erecta L.) & $\begin{array}{l}\text { SC- } \mathrm{CO}_{2} \text { extraction of lutein esters from marigold with soybean oil as a co-solvent was performed. Results showed that the data could } \\
\text { be well fitted to a second-order polynomial model with a } \mathrm{R}^{2} \text {-value of } 0.9398 \text {. The model predicted that the optimal conditions were } \\
35.5 \mathrm{MPa}, 58.7^{\circ} \mathrm{C}, \mathrm{CO}_{2} \text { flow rate of } 19.9 \mathrm{~L} / \mathrm{h} \text { with } 6.9 \% \text { of soybean oil as a co-solvent, and under such conditions, the maximum yield } \\
\text { of } 1.04 \mathrm{~g} \text { lutein } / 100 \mathrm{~g} \text { marigold could be achieved. }\end{array}$ & [100] \\
\hline & Marigold (Tagetes erecta L.) & $\begin{array}{l}\text { Medium-chain triglycerides }(\mathrm{MCTs}) \text {, sunflower seed oil, soybean oil, rapeseed oil and n-hexane were used as co-solvents to promote } \\
\text { supercritical carbon dioxide }\left(\mathrm{SC}-\mathrm{CO}_{2}\right) \text { extraction of lutein esters from marigold (Tagetes erecta } \mathrm{L} \text {.). The optimum extraction conditions } \\
\text { within the experimental range were predicted to be: extraction pressure of } 46.8 \mathrm{MPa} \text {, temperature of } 65.9^{\circ} \mathrm{C} \text { and } \mathrm{MCT} \text { concentration } \\
\text { of } 1.5 \%\left(w / w \text { of } \mathrm{CO}_{2}\right) \text {, with a } \mathrm{CO}_{2} \text { flow rate of } 10 \mathrm{~kg} / \mathrm{h} \text { and extraction time of } 3 \mathrm{~h} \text {. The maximum yield of lutein esters under these } \\
\text { conditions was predicted to be } 1.3 \mathrm{~g} / 100 \mathrm{~g} \text { marigold. }\end{array}$ & [101] \\
\hline
\end{tabular}

ail to solid material ratio $(\mathrm{mL} / \mathrm{g}){ }^{\mathrm{b}}$ Oil to liquid extracts ratio $(\mathrm{mL} / \mathrm{mL})$. 


\section{Conclusions and Future Perspectives}

Alternative solvents from renewable resources for extraction, purification and formulation of natural and food products have attracted a lot of attention in recent years. In this sense, this review gives an overview about the use of different vegetable oils as solvents in the extraction of natural products, preparation of enriched oils with various bioactive compounds from natural sources and formulation of products with applications in food and cosmetic industries. Subsequently, this review presents a discussion of polar paradox theory that illustrates the paradoxical behavior of antioxidants in different media and explains the fact that polar or hydrophilic antioxidants with high HLB values are more effective in non-polar media such as vegetable oils whereas nonpolar or lipophilic antioxidants with low HLB values tend to be more effective in more polar media such as oil-water emulsions. Likewise, the use of a powerful and time-saving COSMO-RS simulation tool is presented to combine a dielectric continuum solvation model and a thermodynamic treatment of the molecular interactions, which could help to predict the solubilization of one molecule in different complex solvents like vegetable oils. In addition, the solvent property of vegetable oils and their applications with innovative techniques (e.g., ultrasound, microwave, supercritical fluids, etc.) for the extraction of different compounds from natural bio-resources has also been reviewed. These greener techniques could offer significant benefits in terms of cost, time, energy and environment, and have shown their potential for an industrial-scale application in food, nutraceutical and cosmetics industries. On the other hand, the excellent natural properties of vegetable oils such as global wide availability, biodegradability, low cost and excellent environmental aspects (i.e., low ecotoxicity and low toxicity toward humans), are advantages in the development of value-added products, for instance, the preparation of oils enriched with medium or high polarity bioactive compounds. To achieve this goal, vegetable oils can be modified in order to modulate their polarity and increase their dissolving power in the extraction of polar bioactive compounds with applications in different industrial sectors.

Vegetable oils have been used as solvents for extraction, purification and formulation by ancient civilizations such as Egyptians and Phoenicians, Indians and Chinese, and even Mayas and Aztecs. The challenges launched by the environmental protection and competitiveness of the globalized market strongly require innovations that break away from the past rather than simple continuity. Vegetable oils could be one of the solutions coming from the past and acting as a future of humanity as an ecologic and an economic alternative to petroleum and hazardous solvents, and turning to sustainability in the 21th century. We are totally convinced that this review is only a starting point for future scientific innovations in this new area "vegetable oils as functional ingredients, reagents and solvents" which is already a success story of collaboration between research, industry and education, covering large ecologic and economic applications: perfume, cosmetic, pharmaceutical, food ingredients, nutraceuticals, biofuels, or fine chemicals industries, for processes such as extraction, formulation, purification, pollution remediation, lubrication, and so on.

Acknowledgments: Edinson Yara Varón thanks to fellowship funding (No. TECSPR14-2-0029) from the People Programme (Marie Curie Actions) of the Seventh Framework Programme of the European Union (FP7/2007-2013) under REA grant agreement No. 600388 (TECNIOspring programme), and from the Agency for Business Competitiveness of the Government of Catalonia, ACCIÓ. Ying Li would like to thank the National Natural Science Foundation of China (Grant 31701633) and the Fundamental Research Funds for the Central Universities (Grant 17817028), as well as special funds from "SanWu Talent 2014" and sixth "100-Talent" Programs. The academic and technical support from Avignon University (France), Jinan University (China) and Lleida University (Spain) are also gratefully acknowledged.

Conflicts of Interest: The authors declare no conflict of interest.

\section{References}

1. Olson, R. Technology and Science in Ancient Civilizations; Praeger: Santa Barbara, CA, USA, 2010; pp. 183-207, ISBN 978-0-275-98936-1. 
2. Pitts, M.; Dorling, D.; Pattie, C. Oil for food: The global story of edible lipids. J. World Syst. Res. 2007, 13, 12-32. [CrossRef]

3. Horden, P.; Purcell, N. The Corrupting Sea: A Study of Mediterranean History; Wiley-Blackwell: Oxford, UK, 2000; p. 761, ISBN 978-0-631-21890-6.

4. Berdick, M. The role of fats and oils in cosmetics. J. Am. Oil Chem. Soc. 1972, 49, 406-408. [CrossRef] [PubMed]

5. Tannahill, R. The near east, egypt and europe. In Food in History; Three Rivers Press: New York, NY, USA, 1989; pp. 43-88.

6. Honary, L.; Richter, E. Biobased Lubricants and Greases: Technology and Products. In Biobased Lubricants and Greases: Technology and Products, 1st ed.; John Wiley \& Sons, Ltd.: West Sussex, UK, 2011; pp. 1-8, ISBN 978-0-470-74158-0.

7. Yang, S. The Divine Farmer's Materia Medica: A Translation of the Shen Nong Ben Cao Jing; Blue Poppy Press: Boulder, CO, USA, 1998; ISBN 9780936185965.

8. Li, S. Compendium of Materia Medica: Bencao Gangmu; Luo, X., Ed.; Foreign Languages Press: Beijing, China, 2004; ISBN 7119032607.

9. Indexmundi. Available online: http://www.indexmundi.com/commodities/?commodity (accessed on 4 August 2017).

10. Purcaro, G.; Barp, L.; Beccaria, M.; Conte, L.S. Characterisation of minor components in vegetable oil by comprehensive gas chromatography with dual detection. Food Chem. 2016, 212, 730-738. [CrossRef] [PubMed]

11. Kamal-Eldin, A. Minor components of fats and oils. In Bailey's Industrial Oil and Fat Products, 6th ed.; Shahidi, F., Ed.; John Wiley \& Sons, Inc.: Hoboken, NJ, USA, 2005; pp. 319-359, ISBN 9780471678496.

12. Aluyor, E.O.; Ozigagu, C.E.; Oboh, O.I.; Aluyor, P. Chromatographic analysis of vegetable oils: A review. Sci. Res. Essays 2009, 4, 191-197.

13. Chen, B.; McClements, D.J.; Decker, E.A. Minor components in food oils: A critical review of their roles on Lipid oxidation chemistry in bulk oils and emulsions. Crit. Rev. Food Sci. Nutr. 2011, 51, 901-916. [CrossRef] [PubMed]

14. Kittipongpittaya, K.; Panya, A.; Cui, L.; McClements, D.J.; Decker, E.A. Association colloids formed by multiple surface active minor components and their effect on lipid oxidation in bulk oil. J. Am. Oil Chem. Soc. 2014, 91, 1955-1965. [CrossRef]

15. Boskou, D. Olive oil. In Vegetable Oils in food Technology: Composition, Properties and Uses, 2nd ed.; Gustone, F.D., Ed.; Wiley-Blackwell: Chichester, UK, 2011; pp. 271-273, ISBN 978-1-4443-3268-1.

16. McClements, D.J. Nanoparticle- and Microparticle-Based Delivery Systems: Encapsulation, Protection and Release of Active Compounds; CRC Press: Boca Raton, FL, USA, 2014; pp. 149-190. ISBN 978-1-4822-3315-5.

17. McClements, D.J. Food Emulsions: Principles, Practice and Techniques, 2nd ed.; CRC Press: Boca Raton, FL, USA, 2004; pp. 99-176, ISBN 9780849320231.

18. Schneider, M. Phospholipids, in Lipid Technologies and Applications; Gunstone, F.D., Padley, F.B., Eds.; Marcel Dekker Inc.: New York, NY, USA, 1997; pp. 51-78, ISBN-13 978-0824798383.

19. Marten, B.; Pfeuffer, M.; Schrezenmeir, J. Medium-chain triglycerides. Int. Dairy J. 2006, 16, $1374-1382$. [CrossRef]

20. Hendriks, H.F.; Weststrate, J.A.; Van Vliet, T.; Meijer, G.W. Spreads enriched with three different levels of vegetable oil sterols and the degree of cholesterol lowering in normocholesterolaemic and mildly hypercholesterolaemic subjects. Eur. J. Clin. Nutr. 1999, 53, 319-327. [CrossRef] [PubMed]

21. Reische, D.W.; Lillard, D.A.; Eitenmiller, R.R. Antioxidants. In Food Lipids: Chemistry, Nutrition, and Biotechnology, 2nd ed.; Akoh, C.C., Min, D.B., Eds.; Marcel Dekker, Inc.: New York, NY, USA, 2002; ISBN 0-8247-0749-4.

22. Chaiyasit, W.; Elias, R.J.; Mcclements, D.J.; Decker, E.A. Role of physical structures in bulk oils on lipid oxidation. Crit. Rev. Food Sci. Nutr. 2007, 47, 299-317. [CrossRef] [PubMed]

23. Zawistowski, J. Tangible health benefits of phytosterol functional foods. In Functional Food Product Development; Smith, J., Charter, E., Eds.; John Wiley \& Sons, Ltd.: Chichester, UK, 2010; pp. 362-387, ISBN 978-1-4051-7876-1.

24. Burton, G.W.; Traber, M.G. Vitamin E: Antioxidant activity, biokinetics, and bioavailability. Ann. Rev. Nutr. 1990, 10, 357-382. [CrossRef] [PubMed] 
25. Van Acker, S.A.B.E.; Koymans, L.M.H.; Bast, A. Molecular pharmacology of vitamin E: Structural aspects of antioxidant activity. Free Rad. Biol. Med. 1993, 15, 311-328. [CrossRef]

26. Combs, G.F., Jr. The Vitamins, 4th ed.; Elsevier Academic Press: Burlington, MA, USA, 2012; pp. 181-211, ISBN 9780128102442.

27. Ramamurthi, S.; MeCurdy, A.R.; Tyler, R.T. Deodorizer distillate: A valuable byproduct. In Proceeding World Conference of Oilseed and Edible Oils Process; Koseoglu, S.S., Rhee, K.C., Wilson, R.F., Eds.; AOCS Press: Champaign, IL, USA, 1998; pp. 130-134, ISBN 0935315845.

28. Johnson, L.A. Recovery, refining, converting, and stabilizing edible fats and oils. In Food Lipids: Chemistry, Nutrition, and Biotechnology, 3rd ed.; Akoh, C.C., Min, D.B., Eds.; Marcel Dekker: New York, NY, USA, 2002; pp. 205-244, ISBN-13 978-1-4200-4663-2.

29. Xenakis, A.; Papadimitriou, V.; Sotiroudis, T.G. Colloidal structures in natural oils. Curr. Opin. Colloid Int. Sci. 2010, 15, 55-60. [CrossRef]

30. Chaiyasit, W.; McClements, D.J.; Weiss, J.; Decker, E.A. Impact of surface-active compounds on physicochemical and oxidative properties of edible oil. J. Agric. Food Chem. 2008, 56, 550-556. [CrossRef] [PubMed]

31. Galli, C.; Petroni, A.; Visioli, F. Natural antioxidants, with special reference to those in olive oil, and cell protection. Eur. J. Pharm. Sci. 1994, 2, 67-68. [CrossRef]

32. Cert, A.; Moreda, W.; Pérez-Camino, M.C. Chromatographic analysis of minor constituents in vegetable oils. J. Chromatogr. A 2000, 881, 131-148. [CrossRef]

33. Hidalgo, F.J.; Alaiz, M.; Zamora, R. Determination of peptides and proteins in fats and oils. Anal. Chem. 2001, 73, 698-702. [CrossRef] [PubMed]

34. Hidalgo, F.J.; Zamora, R. Peptides and proteins in edible oils: Stability, allergenicity, and new processing trends. Trends Food Sci. Technol. 2006, 17, 56-63. [CrossRef]

35. Capello, C.; Fischer, U.; Hungerbühler, K. What is a green solvent? A comprehensive framework for the environmental assessment of solvent. Green Chem. 2007, 9, 927-934. [CrossRef]

36. Baiano, A.; Gambacorta, G.; La Notte, E. Aromatization of Olive Oil; Transworld Research Network: Kerala, India, 2010; pp. 1-29, ISBN 978-81-7895-462-2.

37. Clark, J.H.; Farmer, T.J.; Hunt, A.J.; Sherwood, J. Opportunities for bio-based solvents created as petrochemical and fuel products transition towards renewable resources. Int. J. Mol. Sci. 2015, 16, 17101-17159. [CrossRef] [PubMed]

38. Chen, H.M.; Meyers, S.P. Extraction of astaxanthin pigment from crawfish waste using a soy oil process. J. Food Sci. 1982, 47, 892-896. [CrossRef]

39. Antoun, N.; Tsimidou, M. Gourmet olive oils: Stability and consumer acceptability studies. Food Res. Int. 1997, 30, 131-136. [CrossRef]

40. Marinova, E.M.; Yanishlieva, N.V. Antioxidant activity of extracts from selected species of the family Lamiaceae in sunflower oil. Food Chem. 1997, 58, 245-248. [CrossRef]

41. Damechki, M.; Sotiropoulou, S.; Tsimidou, A. Antioxidant and pro-oxidant factors in oregano and rosemary gourmet olive oils. Grasas Aceites 2001, 52, 207-213. [CrossRef]

42. Husken, H.; Kooij, S.; Van Putte, K.P. Oil Having Increased Polyphenol Content. U.S. Patent 0172751 A1, 21 November 2002.

43. Van Boom, S.S.; Van der Brugghen, R.; Maitland, R. Method for Flavoring an Olive Oil. U.S. Patent 0164413 A1, 7 November 2002.

44. Moldão-Martins, M.; Beirão-da-Costa, S.; Neves, C.; Cavaleiro, C.; Salgueiro, L.; Beirão-da-Costa, M.L. Olive oil flavoured by the essential oils of Mentha $\times$ piperita and Thymus mastichina L. Food Qual. Prefer. 2004, 15, 447-452. [CrossRef]

45. Sachindra, N.M.; Mahendrakar, N.S. Process optimization for extraction of carotenoids from shrimp waste with vegetable oils. Bioresour. Technol. 2005, 96, 1195-1200. [CrossRef] [PubMed]

46. Gambacorta, G.; Faccia, M.; Pati, S.; Lamacchia, C.; Baiano, A. Changes in the chemical and sensorial profile of extra virgin olive oils flavored with herbs and spices during storage. J. Food Lipids 2007, 14, 202-215. [CrossRef]

47. Chiou, A.; Salta, F.N.; Kalogeropoulos, N.; Mylona, A.; Ntalia, I.; Andrikopoulos, N.K. Retention and distribution of polyphenols after pan-frying of French fries in oils enriched with olive leaf extract. J. Food Sci. 2007, 72, 574-584. [CrossRef] [PubMed] 
48. Rao, A.R.; Sarada, R.; Ravishankar, G.A. Stabilization of astaxanthin in edible oils and its use as an antioxidant. J. Sci. Food Agric. 2007, 87, 957-965. [CrossRef]

49. Handayani, A.D.; Sutrisno; Indraswati, N.; Ismadji, S. Extraction of astaxanthin from giant tiger (Panaeus monodon) shrimp waste using palm oil: Studies of extraction kinetics and thermodynamic. Bioresour. Technol. 2008, 99, 4414-4419. [CrossRef] [PubMed]

50. Kang, C.D.; Sim, S.J. Direct extraction of astaxanthin from Haematococcus culture using vegetable oils. Biotechnol. Lett. 2008, 20, 441-444. [CrossRef] [PubMed]

51. Ayadi, M.A.; Grati-Kamoun, V.; Attia, H. Physico-chemical change and heat stability of extra virgin olive oils flavoured by selected Tunisian aromatic plants. Food Chem. Toxicol. 2009, 47, 2613-2619. [CrossRef] [PubMed]

52. Karoui, I.J.; Wannes, W.A.; Marzouk, B. Refined corn oil aromatization by Citrus aurantium peel essential oil. Ind. Crop. Prod. 2010, 32, 202-207. [CrossRef]

53. Pu, J.; Bechtel, P.J.; Sathivel, S. Extraction of shrimp astaxanthin with flaxseed oil: Effects on lipid oxidation and astaxanthin degradation rates. Biosyst. Eng. 2010, 107, 364-371. [CrossRef]

54. Suárez, M.; Romero, M.P.; Motilva, M.J. Development of phenol-enriched olive oil with phenolic compounds from olive cake. J. Agric. Food Chem. 2010, 58, 10396-10403. [CrossRef] [PubMed]

55. Suárez, M.; Romero, M.P.; Ramo, T.; Motilva, M.J. Stability of a phenol-enriched olive oil during storage. Eur. J. Lipid Sci. Technol. 2011, 113, 894-903. [CrossRef]

56. Orozco, M.I.; Priego-Capoto, F.; Luque de Castro, M.D. Influence of deep frying on the unsaponifiable fraction of vegetable edible oils enriched with natural antioxidants. J. Agric. Food Chem. 2011, 59, 7194-7202. [CrossRef] [PubMed]

57. Karoui, I.J.; Dhifi, W.; Jemia, M.B.; Marwouk, B. Thermal stability of corn oil flavoured with Thymus capitatus under heating and deep-frying conditions. J. Sci. Food Agric. 2011, 91, 927-933. [CrossRef] [PubMed]

58. Orozco-Solano, M.I.; Priego-Capoto, F.; Luque de Castro, M.D. Influence of simulated deep frying on the antioxidant fraction of vegetable oils after enrichment with extracts from olive oil pomace. J. Agric. Food Chem. 2011, 59, 9806-9814. [CrossRef] [PubMed]

59. Sánchez de Medina, V.; Priego-Capote, F.; Luque de Castro, M.D. Characterization of refined edible oils enriched with phenolic extracts from olive leaves and pomace. J. Agric. Food Chem. 2012, 60, 5866-5873. [CrossRef] [PubMed]

60. Nevado, J.J.B.; Robledo, V.R.; Callado, C.S. Monitoring the enrichment of virgin olive oil with natural antioxidants by using a new capillary electrophoresis method. Food Chem. 2012, 133, 497-504. [CrossRef] [PubMed]

61. Aydeniz, B.; Yilmaz, E. Enrichment of frying oils with plant phenolic extracts to extend the usage life. Eur. J. Lipid Sci. Technol. 2012, 114, 933-941. [CrossRef]

62. García-Martínez, O.; Mazzaglia, G.; Sánchez-Ortiz, A.; Ocaña-Peinado, F.M.; Rivas, A. Phenolic content of Sicilian virgin olive oils and their effect on MG-63 human osteoblastic cell proliferation. Grasas Aceites 2014, 65, e032. [CrossRef]

63. Zaru, M.; Tronci, M.B.; Biggio, G.; Biggio, T.; Piras, C.; Boi, B.; Boi, I.; Boi, M.; Boi, S.; Boi, C.; et al. Oily Extract of Plants of Rubus Species and Uses Thereof in Medical and Cosmetic Fields. U.S. Patent 20160113984 A1, 11 June 2014.

64. Valls, R.M.; Farràs, M.; Suárez, M.; Fernández-Castillejo, S.; Fitó, M.; Konstantinidou, V.; Fuentes, F.; López-Miranda, J.; Giralt, M.; Covas, M.I.; et al. Effects of functional olive oil enriched with its own phenolic compounds on endothelial function in hypertensive patients. A randomised controlled trial. Food Chem. 2015, 167, 30-35. [CrossRef] [PubMed]

65. Karoui, I.J.; Msaada, K.; Abderrabba, M.; Marzouk, B. Bioactive compounds and antioxidant activities of thyme-enriched refined corn oil. J. Agric. Sci. Technol. 2016, 18, 79-91.

66. Romeu, M.; Rubió, L.; Sánchez-Martos, V.; Castañer, O.; de la Torre, R.; Valls, R.M.; Ras, R.; Pedret, A.; Catalán, Ú.; de las Hazas, H.; et al. Virgin olive oil enriched with its own phenols or complemented with thyme phenols improves DNA protection against oxidation and antioxidant enzyme activity in hyperlipidemic subjects. J. Agric. Food Chem. 2016, 64, 1879-1888. [CrossRef] [PubMed]

67. Buttery, R.G.; Guadagni, D.G.; Ling, L.C. Flavor compounds: Volatilities in vegetable oil and oil-water mixtures. Estimation of odor thresholds. J. Agric. Food Chem. 1973, 21, 198-201. [CrossRef] 
68. Li, Y.; Fabiano-Tixier, A.S.; Ginies, C.; Chemat, F. Direct green extraction of volatile aroma compounds using vegetable oils as solvents: Theoretical and experimental solubility study. LWT_Food Sci. Technol. 2014, 59, 724-731. [CrossRef]

69. Li, Y.; Fabiano-Tixier, A.S.; Ruiz, K.; Rossignol-Castera, A.; Bauduin, P.; Diat, O.; Chemat, F. Comprehension of direct extraction of hydrophilic antioxidants using vegetable oils by polar paradox theory and small angle X-ray scattering analysis. Food Chem. 2015, 173, 873-880. [CrossRef] [PubMed]

70. Fréville, V. Caractérisation et Évaluation des Performances de Nouveaux Solvants Synthétisés à Partir D'agroressources; Université de Technologie de Compiègne: Compiègne, France, 2011.

71. Chemat, F.; Vian, M. Alternative Solvents for Natural Products Extraction; Springer: Heidelberg, Germany, 2014; pp. v-vi, ISBN 978-3-662-43627-1.

72. Reichardt, C. Solvents and solvent effects: An introduction. Org. Process Res. Dev. 2007, 11, 105-113. [CrossRef]

73. Vijayendran, B. Bio products from bio refineries-Trends, challenges and opportunities. J. Bus. Chem. 2010, 7, 109-115.

74. De Caro, P.; Thiebaud-Roux, S. Biosolvants. Available online: http://www.techniques-ingenieur.fr/ base-documentaire/archives-th12/archives-eco-conception-et-innovation-responsable-tiaeco/archive-1/ biosolvants-in102/ (accessed on 1 August 2017).

75. Henderson, R.K.; Jiménez-González, C.; Constable, D.J.C.; Alston, S.R.; Inglis, G.G.A.; Fisher, G.; Sherwood, J.; Binks, S.P.; Curzons, A.D. Expanding GSK's solvent selection guide-Embedding sustainability into solvent selection starting at medicinal chemistry. Green Chem. 2011, 13, 854-862. [CrossRef]

76. Prat, D.; Pardigon, O.; Flemming, H.W.; Letestu, S.; Ducandas, V.; Isnard, P.; Guntrum, E.; Senac, T.; Ruisseau, S.; Cruciani, P.; et al. Sanofi's solvent selection guide: A step toward more sustainable processes. Org. Process Res. Dev. 2013, 17, 1517-1525. [CrossRef]

77. Hargreaves, C.R.; Manley, J.B. Collaboration to Deliver a Solvent Selection Guide for the Pharmaceutical Industry. Available online: https:/ /www.acs.org/content/dam/acsorg/greenchemistry/ industriainnovation/roundtable/solvent-selection-guide.pdf (accessed on 1 August 2017).

78. Diorazio, L.J.; Hose, D.R.J.; Adlington, N.K. Toward a more holistic framework for solvent selection. Org. Process Res. Dev. 2016, 20, 760-773. [CrossRef]

79. Alfonsi, K.; Colberg, J.; Dunn, P.J.; Fevig, T.; Jennings, S.; Johnson, T.A.; Kleine, H.P.; Knight, C.; Nagy, M.A.; Perry, D.A.; et al. Green chemistry tools to influence a medicinal chemistry and research chemistry based organisation. Green Chem. 2008, 10, 31-36. [CrossRef]

80. Moity, L.; Durand, M.; Benazzouz, A.; Molinier, V.; Aubry, J.M. In silico search for alternative green solvents. In Alternative Solvents for Natural Products Extraction; Chemat, F., Vian, M.A., Eds.; Springer: Heidelberg/Germany, Germany, 2014; pp. 1-24, ISBN 978-3-662-43627-1.

81. Kerton, F.; Marriott, R. Alternative Solvents for Green Chemistry, 2nd ed.; RSC Publishing: Cambridge, UK, 2013; pp. 149-171, ISBN 978-1-84973-595-7.

82. Li, Y.; Fabiano-Tixier, A.S.; Tomao, V.; Cravotto, G.; Chemat, F. Green ultrasound-assisted extraction of carotenoids based on the bio-refinery concept using sunflower oil as an alternative solvent. Ultrason. Sonochem. 2013, 20, 12-18. [CrossRef] [PubMed]

83. Chevereau, P. Method for Extracting and Fixing Aromas on Non-Aqueous Substrate, Machine for Implementing the Method, and Product Thereby. U.S. Patent US5853726, 29 December 1998.

84. Rossignol-Castera, A. Methods for Extracting Non-Volatile Compounds. International Patent WO 2010112760 A1, 7 October 2010.

85. Porter, W.L. Recent trends in food applications of antioxidants. In Autoxidation in Food and Biological Systems; Simic, M.G., Karel, M., Eds.; Springer: New York, NY, USA, 1980; pp. 295-365, ISBN 978-1-4757-9353-6.

86. Porter, W.L. Paradoxical behavior of antioxidants in food and biological systems. In Antioxidant: Chemical, Physiological, Nutritional and Toxicological Aspects; Williams, G.M., Ed.; Princeton Scientific: Princeton, NJ, USA, 1993; pp. 93-122, ISBN-13 978-0911131499.

87. Frankel, E.; Huang, S.W.; Kanner, J.; German, J.B. Interfacial phenomena in the evaluation of antioxidants: Bulk oils vs. emulsions. J. Agric. Food Chem. 1994, 42, 1054-1059. [CrossRef]

88. Frankel, E.N.; Huang, S.W.; Aeschbach, R.; Prior, E. Antioxidant activity of a rosemary extract and its constituents, carnosic acid, carnosol, and rosmarinic acid, in bulk oil and oil-in-water emulsion. J. Agric. Food Chem. 1996, 44, 131-135. [CrossRef] 
89. Zhong, Y.; Shahidi, F. Antioxidant behavior in bulk oil: Limitations of polar paradox theory. J. Agric. Food Chem. 2012, 60, 4-6. [CrossRef] [PubMed]

90. Budilarto, E.S.; Kamal-Eldin, A. The supramolecular chemistry of lipid oxidation and antioxidation in bulk oils. Eur. J. Lipid Sci. Technol. EJLST 2015, 117, 1095-1137. [CrossRef] [PubMed]

91. Garti, N. Microemulsions as microreactors for food applications. Curr. Opin. Colloid Interface Sci. 2003, 8, 197-211. [CrossRef]

92. Li, Y.; Fabiano-Tixier, A.S.; Chemat, F. Vegetable oils as alternative solvents for green extraction of natural products. In Edible Oils: Extraction, Processing, and Applications; Chemat, S., Ed.; CRC Press: Boca Raton, FL, USA, 2017; pp. 205-222, ISBN 978-1-4987-5209-1.

93. Cartier, A.; Rivail, J.L. Electronic descriptors in quantitative structure-activity relationships. Chemom. Intell. Lab. Syst. 1987, 1, 335-347. [CrossRef]

94. Klamt, A. Prediction of the mutual solubilities of hydrocarbons and water with COSMO-RS. Fluid Phase Equilib. 2003, 206, 223-235. [CrossRef]

95. Sun, M.; Temelli, F. Supercritical carbon dioxide extraction of carotenoids from carrot using canola oil as a continuous co-solvent. J. Supercrit. Fluids 2006, 37, 397-408. [CrossRef]

96. Prado, J.M.; Veggi, P.C.; Meireles, M.A.A. Extraction Methods for Obtaining Carotenoids from Vegetables. Curr. Anal. Chem. 2014, 10, 29-66. [CrossRef]

97. Vasapollo, G.; Longo, L.; Rescio, L.; Ciurlia, L. Innovative supercritical $\mathrm{CO}_{2}$ extraction of lycopene from tomato in the presence of vegetable oil as cosolvent. J. Supercrit. Fluids 2004, 29, 87-96. [CrossRef]

98. Shi, J.; Yi, C.; Xue, S.J.; Jiang, Y.M.; Ma, Y.; Li, D. Effects of modifiers on the profile of lycopene extracted from tomato skins by supercritical $\mathrm{CO}_{2}$. J. Food Eng. 2009, 93, 431-436. [CrossRef]

99. Saldaña, M.D.A.; Temelli, F.; Guigard, S.E.; Tomberli, B.; Gray, C.G. Apparent solubility of lycopene and $\beta$-carotene in supercritical $\mathrm{CO}_{2}, \mathrm{CO}_{2}+$ ethanol and $\mathrm{CO}_{2}+$ canola oil using dynamic extraction of tomatoes. J. Food Eng. 2010, 99, 1-8. [CrossRef]

100. Ma, Q.; Xu, X.; Gao, Y.; Wang, Q.; Zhao, J. Optimisation of supercritical carbon dioxide extraction of lutein esters from marigold (Tagetes erecta L.) with soybean oil as a co-solvent. Int. J. Food Sci. Technol. 2008, 43, 1763-1769. [CrossRef]

101. Gao, Y.; Liu, X.; Xu, H.G.; Zhao, J.; Wang, Q.; Liu, G.M.; Hao, Q.F. Optimization of supercritical carbon dioxide extraction of lutein esters from marigold (Tagetes erecta L.) with vegetable oils as continuous co-solvents. Sep. Purif. Technol. 2010, 71, 214-219. [CrossRef]

102. Luque-García, J.L.; Luque de Castro, M.D. Ultrasound-assisted soxhlet extraction: An expeditive approach for solid sample treatment: Application to the extraction of total fat from oleaginous seeds. J. Chromatogr. A 2004, 1034, 237-242. [CrossRef] [PubMed]

103. Djenni, Z.; Pingret, D.; Mason, T.J.; Chemat, F. Sono-Soxhlet: In situ ultrasound-assisted extraction of food products. Food Anal. Methods 2013, 6, 1229-1233. [CrossRef]

104. Pingret, D.; Fabiano-Tixier, A.-S.; Chemat, F. An Improved Ultrasound Clevenger for Extraction of Essential Oils. Food Anal. Methods 2014, 7, 9-12. [CrossRef]

105. Cravotto, G.; Boffa, L.; Mantegna, S.; Perego, P.; Avogadro, M.; Cintas, P. Improved extraction of vegetable oils under high-intensity ultrasound and/or microwaves. Ultrason. Sonochem. 2008, 15, 898-902. [CrossRef] [PubMed]

106. Cravotto, G.; Cintas, P. The combined use of microwaves and ultrasound: Improved tools in process chemistry and organic synthesis. Chem. Eur. J. 2007, 13, 1902-1909. [CrossRef] [PubMed]

107. Allaf, T.; Tomao, V.; Ruiz, K.; Chemat, F. Instant controlled pressure drop technology and ultrasound assisted extraction for sequential extraction of essential oil and antioxidants. Ultrason. Sonochem. 2013, 20, 239-246. [CrossRef] [PubMed]

108. Balachandran, S.; Kentish, S.E.; Mawson, R.; Ashokkumar, M. Ultrasonic enhancement of the supercritical extraction from ginger. Ultrason. Sonochem. 2006, 13, 471-479. [CrossRef] [PubMed]

109. Chen, J.; Chen, Y.; Li, H.; Lai, S.Y.; Jow, J. Physical and chemical effects of ultrasound vibration on polymer melt in extrusion. Ultrason. Sonochem. 2010, 17, 66-71. [CrossRef] [PubMed]

110. Mousavi, S.A.A.A.; Feizi, H.; Madoliat, R. Investigations on the effects of ultrasonic vibrations in the extrusion process. J. Mater. Process. Technol. 2007, 187, 657-661. [CrossRef] 
111. Chemat, F.; Rombaut, N.; Sicaire, A.-G.; Meullemiestre, A.; Fabiano-Tixier, A.-S.; Abert-Vian, M. Ultrasound assisted extraction of food and natural products. Mechanisms, techniques, combinations, protocols and applications. A review. Ultrason. Sonochem. 2017, 34, 540-560. [CrossRef] [PubMed]

112. Krichnavaruk, S.; Shotipruk, A.; Goto, M.; Pavasant, P. Supercritical carbon dioxide extraction of astaxanthin from Haematococcus pluvialis with vegetable oils as co-solvent. Bioresour. Technol. 2008, 99, 5556-5560. [CrossRef] [PubMed]

113. Japon-Lujan, R.; Janeiro, P.; Luque de Castro, M.D. Solid-liquid transfer of biophenols from olive leaves for the enrichment of edible oils by a dynamic ultrasound-assisted approach. J. Agric. Food Chem. 2008, 56, 7231-7235. [CrossRef] [PubMed]

114. Veillet, S.; Tomao, V.; Chemat, F. Ultrasound assisted maceration: An original procedure for direct aromatization of olive oil with basil. Food Chem. 2010, 123, 905-911. [CrossRef]

115. Achat, S.; Tomao, V.; Madani, K.; Chibane, M.; Elmaataoui, M.; Dangles, O.; Chemat, F. Direct enrichment of olive oil in oleuropein by ultrasound-assisted maceration at laboratory and pilot plant scale. Ultrason. Sonochem. 2012, 19, 777-786. [CrossRef] [PubMed]

116. Chemat, F.; Périno-Issartier, S.; Loucif, L.; Elmaataoui, M.; Mason, T.J. Enrichment of edible oil with sea buckthorn by-products using ultrasound-assisted extraction. Eur. J. Lipid Sci. Technol. 2012, 114, 453-460. [CrossRef]

117. Purohit, A.J.; Gogate, P.R. Ultrasound-assisted extraction of $\beta$-carotene from waste carrot residue: Effect of operating parameters and type of ultrasonic irradiation. Sep. Sci. Technol. 2015, 50, 1507-1517. [CrossRef]

118. Goula, A.M.; Ververi, M.; Adamopoulou, A.; Kaderides, K. Green ultrasound-assisted extraction of carotenoids from pomegranate wastes using vegetable oils. Ultrason. Sonochem. 2017, 34, 821-830. [CrossRef] [PubMed]

119. Paduano, A.; Caporaso, N.; Santini, A.; Sacchi, R. Microwave and ultrasound-assisted extraction of capsaicinoids from chili peppers (Capsicum annuum L.) in flavored olive oil. J. Food Res. 2014, 3, 51-59. [CrossRef]

120. Japón-Luján, R.; Luque de Castro, M.D. Liquid-liquid extraction for the enrichment of edible oils with phenols from olive leaf extracts. J. Agric. Food Chem. 2008, 56, 2505-2511. [CrossRef] [PubMed]

121. Girón, M.V.; Ruiz-Jiménez, J.; Luque de Castro, M.D. Dependence of fatty-acid composition of edible oils on their enrichment in olive phenols. J. Agric. Food Chem. 2009, 57, 2797-2802. [CrossRef] [PubMed]

122. Combes, C.; Dugas, E.; Gaëlle, C. Method for Obtaining an Oily Extract of Plants. France Patent FR3011848B1, April 2015.

123. Leconte, N.; Rossignol-Castera, A. Use of an Oily Composition Containing an Extract of Daylily in Order to Improve the Firmness of the Skin. International Patent WO2015049268 A1, 9 April 2015.

124. Gouveia, A.F.; Duarte, C.; Beirão da Costa, M.L.; Bernardo-Gil, M.G.; Moldão-Martins, M. Oxidative stability of olive oil flavoured by Capsicum frutescens supercritical fluid extracts. Eur. J. Lipid Sci. Technol. 2006, 108, 421-428. [CrossRef]

(C) 2017 by the authors. Licensee MDPI, Basel, Switzerland. This article is an open access article distributed under the terms and conditions of the Creative Commons Attribution (CC BY) license (http:// creativecommons.org/licenses/by/4.0/). 